\title{
Waking the undead: implications of a soft explosive model for the timing of placental mammal diversification
}

\author{
Mark S. Springer ${ }^{\mathrm{a},{ }^{*}}$, Christopher A. Emerling ${ }^{\mathrm{b}}$, Robert W. Meredith ${ }^{\mathrm{c}}$, Jan E. Janečka ${ }^{\mathrm{d}}$, \\ Eduardo Eizirik ${ }^{\mathrm{e}}$, William J. Murphy ${ }^{\mathrm{f}}$
}

\author{
${ }^{a}$ Department of Biology, University of California, Riverside, CA 92521, USA \\ ${ }^{b}$ Museum of Vertebrate Zoology, University of California, Berkeley, CA 94720, USA \\ ${ }^{\mathrm{c}}$ Department of Biology and Molecular Biology, Montclair State University, Montclair, \\ NJ 07043, USA \\ dDepartment of Biological Sciences, Duquesne University, Pittsburgh, PA 15282, USA \\ ${ }^{\mathrm{e}}$ Faculdade de Biociências, Pontifícia Universidade Católica do Rio Grande do Sul, Porto \\ Alegre, RS 90619-900, Brazil \\ ${ }^{\mathrm{f}}$ Department of Veterinary Integrative Biosciences, Texas A\&M University, College \\ Station, TX 77843, USA
}

\begin{abstract}
The explosive, long fuse, and short fuse models represent competing hypotheses for the timing of placental mammal diversification. Support for the explosive model, which posits both interordinal and intraordinal diversification after the KPg mass extinction, derives from morphological cladistic studies that place Cretaceous eutherians outside of crown Placentalia. By contrast, most molecular studies favor the long fuse model wherein interordinal cladogenesis occurred in the Cretaceous followed by intraordinal cladogenesis after the KPg boundary. Phillips (2016) proposed a soft explosive model that allows for the emergence of a few lineages (Xenarthra, Afrotheria, Euarchontoglires, Laurasiatheria) in the Cretaceous, but otherwise agrees with the explosive model in positing the majority of interordinal diversification after the KPg mass extinction. Phillips (2016) argues that rate transference errors associated with large body size and long lifespan have inflated previous estimates of interordinal divergence times, and further suggests that most interordinal divergences are positioned after the KPg boundary when rate transference errors are avoided through the elimination of
\end{abstract}


calibrations in large-bodied and/or long lifespan clades. Here, we show that rate transference errors can also occur in the opposite direction and drag forward estimated divergence dates when calibrations in large-bodied/long lifespan clades are omitted. This dragging forward effect results in the occurrence of more than half a billion years of 'zombie lineages' on Phillips' preferred timetree. By contrast with ghost lineages, which are a logical byproduct of an incomplete fossil record, zombie lineages occur when estimated divergence dates are younger than the minimum age of the oldest crown fossils. We also present the results of new timetree analyses that address the rate transference problem highlighted by Phillips (2016) by deleting taxa that exceed thresholds for body size and lifespan. These analyses recover all interordinal divergence times in the Cretaceous and are consistent with the long fuse model of placental diversification. Finally, we outline potential problems with morphological cladistic analyses of higherlevel relationships among placental mammals that may account for the perceived discrepancies between molecular and paleontological estimates of placental divergence times.

Keywords: divergence time; ghost lineage; long fuse model; placental mammal; zombie lineage

Abbreviations: KPg, Cretaceous-Paleogene; PAML, phylogenetic analysis by maximum likelihood; PAUP, phylogenetic analysis using parsimony

\section{Introduction}

The radiation of placental mammals in relationship to the KPg boundary ( 66 Ma) is one of the most contentious problems in paleontology and systematics. Archibald and Deutschman (2001) suggested three competing models for placental diversification. The explosive model, which is favored by many paleontologists (e.g., O'Leary et al., 2013), posits interordinal and intraordinal diversification after the KPg boundary. This model is underpinned by morphological cladistic analyses that place Cretaceous eutherians outside of crown Placentalia (Wible et al., 2009; O’Leary et al., 2013; Zhou et al., 2013; Chester 
et al., 2015). The long fuse model agrees with the explosive model in positing most intraordinal diversification after the KPg boundary, but positions nearly all interordinal diversification before the KPg boundary. Support for the long fuse model derives from a wide array of molecular timetree analyses (Hasegawa et al., 2003; Springer et al., 2003, 2005; Delsuc et al., 2004; Meredith et al., 2011; dos Reis et al., 2012; Lartillot and Delsuc, 2012; Slater, 2013; Emerling et al., 2015; Foley et al., 2016; Tarver et al., 2016). Archibald and Deutschman's (2001) third model, the short fuse model, posits interordinal and some intraordinal diversification well before the KPg boundary. This model is supported by Bininda-Emonds et al.'s (2007) analysis of a supertree phylogeny with local molecular clocks.

Advocates of the explosive model have argued that both long fuse and short fuse models are in direct conflict with the fossil record because of their implied ghost lineages (O’Leary et al., 2013). However, ghost lineages are a logical extension of an incomplete fossil record and cannot be dismissed out of hand (Springer and Lilje, 1988; Strauss and Sadler, 1989; Marshall, 1990; Springer, 1990; Teeling et al., 2005; Johnson et al., 2006; Meredith et al., 2008). Also, the explosive model is predicated on the accuracy of morphological cladistic analyses that place Cretaceous eutherians outside of Placentalia. Morphological cladistics has a poor track record of recovering superordinal clades of even extant placental mammals and is prone to cluster taxa together based on ecomorphological convergence. Furthermore, most morphological studies utilize matrices in which many of the taxa (fossils) are missing the majority of the characters because of incomplete fossil preservation (Springer et al., 2007a, 2008, 2013; Sansom and Wills, 2013). Finally, the explosive model requires viral-like rates of evolution in mammalian lineages during the interval immediately following the KPg boundary (Springer et al., 2013).

Most recently, Phillips (2016) proposed a fourth model, the soft explosive model, which allows for cladogenic separation of the four major clades of placental mammals (Afrotheria, Xenarthra, Laurasiatheria, Euarchontoglires) in the Cretaceous, but otherwise agrees with the explosive model in positioning the bulk of interordinal diversification in Placentalia after the KPg boundary. Phillips (2016) argued that support for the long fuse model in previous timetree analyses results from rate transference errors that inflate 
estimates of interordinal divergence times, and that most interordinal divergences are positioned after the KPg boundary when rate transference errors are avoided by eliminating calibrations in large-bodied/long lifespan clades that are the source of these errors. Here, we discuss fundamental problems with Phillips' (2016) timetree analyses and show that they result in 'zombie' lineages, which are the antithesis of ghost lineages and occur when estimated divergence dates are younger than minimum ages implied by the fossil record. We show that when divergence dates in large-bodied/long lifespan clades are not calibrated and are underestimated (i.e., too young), as in Phillips (2016), they can drag forward deeper nodes and result in estimates of interordinal divergence times that are in direct conflict with the fossil record. We also present the results of new timetree analyses that circumvent the rate transference problem highlighted by Phillips (2016) by deleting taxa that exceed thresholds for body size and lifespan. The results of these analyses again position all interordinal divergence times in the Cretaceous and support the long fuse model of placental diversification. Finally, we review potential problems with the results of morphological cladistic analyses of higher-level relationships among placental mammals that challenge the stem status of all Cretaceous placentals.

\section{Methods}

\subsection{Molecular dating analyses}

Molecular data analyses with Meredith et al.'s (2011) DNA data set were performed with the mcmctree package in PAML 4.8 (Yang 2007). Analyses were performed with both autocorrelated and independent rates, as well as with hard-bounded and soft-bounded calibrations. Each memctree analysis was run twice to check for convergence. As in Meredith et al. (2011), each gene was allowed to have its own model of sequence evolution following Meredith et al. (2011). We set 1 time unit $=100$ million years. Analyses were run with cleandata $=0$. Shape $(\alpha)$ and scale $(\beta)$ parameters for rgene_gamma, which describes the gamma prior for the overall rate parameter $\mu$, were as in Meredith et al. (2011). Similarly, shape and scale parameters for sigma_gamma, which

describes the gamma prior for the rate-drift parameter $\left(\sigma^{2}\right)$, were taken from Meredith et 
al. (2011). Analyses were run for 100,000 generations following a burn-in of 10,000 generations. Each chain was sampled every 20 generations.

Timetree analyses with too few calibrations in large-bodied/long lifespan clades (Phillips, 2016) may drag divergence times of deeper nodes toward the present owing to underestimation of divergences in the large-bodied clades. Instead of dropping all or most calibrations in large-bodied clades, which would have the effect of forcing rates from small-bodied taxa onto their branches, we employed an alternate strategy (Springer et al., 2003) and excluded taxa with average adult body mass > $10 \mathrm{~kg}$ and/or maximum longevity > 40 years (thresholds suggested by M. Phillips, pers. comm.). Body size data are from Pantheria (Jones et al., 2009) and longevity data are from Magalhães and Costa (2009). The resulting topology included 122 of 169 taxa from Meredith et al. (2011) and excluded all members of Proboscidea, Sirenia, and Perissodactyla; all Cetartiodactyla except for Tragulus (mouse-deer); all Anthropoidea with the exception of Callithrix (marmoset); nine of 16 carnivorans including all three pinnipeds and Ailuropoda (giant panda); and assorted taxa in other clades such as Pteropus (flying fox), Myrmecophaga (giant anteater), and Hydrochoerus (capybara). After excluding these taxa, this 122-taxon data set retained at least one representative of all placental orders except for Proboscidea, Sirenia, Tubulidentata, and Perissodactya. Analyses were performed with an updated set of 62 calibrations that reflect newly described fossils and recommendations from a variety of other timetree studies (Table 1). Analyses were performed with all four combinations of hard-bounded versus soft-bounded constraints and autocorrelated versus independent rates. All four timetrees are available at TreeBASE (http://purl.org/phylo/treebase/phylows/study/TB2:S19854).

\subsection{Parsimony analysis}

Maximum parsimony analyses of Wible et al.'s (2009) data set were performed with PAUP* 4.0a147 (Swofford, 2002). Analyses were performed after excluding Alymlestes because of a high percentage (94.9) of missing data for this taxon. Searches for optimal trees, with or without phylogenetic constraints, employed 100 random addition sequences with tree-bisection and reconnection branch swapping. Trees with 
minimum branch lengths of zero were collapsed using the "-amb" option in PAUP. Templeton and winning-sites tests were also performed with PAUP to compare parsimony scores for different trees to each other.

\subsection{Molecular timetree diversification patterns and the fossil record}

We used the R package paleobioDB (Varela et al. 2014) to acquire eutherian fossil data from each geological stage ranging from the Berriasian (Lower Cretaceous) to the Priabonian (Eocene). For each stage, we downloaded all records of eutherian families, genera, and species, recorded the standing diversity for each taxon, and quantified the number of new taxa in each category. We estimated new lineage accumulation rates for each stage by dividing the number of new lineages by the stage's time duration, and then calculated the percentage increase or decrease across each stage boundary. Stage durations in millions of years were taken from version 2014 of the International Chronostratigraphic Chart (Cohen et al., 2013; www.stratigraphy.org). Next, we performed similar calculations (i.e., number of lineages, number of new lineages, and number of new lineages per million years for each stage, percentage increase or decrease across stage boundary) based on three timetrees: (1) Phillips' (2016) preferred timetree (dR27b) using Meredith et al.'s (2011) DNA supermatrix encompassing 169 species and 27 calibrations from dos Reis et al. (2012), including updated maximum bounds for Chiroptera, Primates, and Rodentia; (2) Phillips' (2016) reanalysis of Meredith et al.'s (2011) DNA supermatrix with 82 calibrations (Mer82c); and (3) Emerling et al.'s (2015)

analysis of 388 species (Emer15). This last timetree included nearly all of the mammalian and outgroup taxa in Meredith et al.'s (2011) supermatrix, plus additional loci (38 total) and 77 fossil calibrations, many of which are updated from Meredith et al. (2011) and also described here. We used the 2010 version of the geological time scale to calculate rates for $\mathrm{dR} 27 \mathrm{~b}$ and Mer82c, and the 2014 version of the geological time scale to calculate rates for Emer15, because these authors employed different versions of the geologic time scale (www.stratigraphy.org). Emer15 records two speciation events prior to the end of the Lutetian that are not represented by Meredith et al.'s (2011) taxon 
sampling (i.e., deep splits in Soricidae and Emballonuridae), so these were excluded from the analyses.

\section{Results and Discussion}

\subsection{Zombie lineages and the "soft explosive model"}

Phillips (2016) argued that correlations between life history and rates of molecular evolution will tend to inflate deep-level divergence estimates among placental mammals because calibrations in clades that have evolved large body size and/or extreme longevity could be susceptible to rate-shift identifiability errors, which may transfer crown rates to stem rates if deeper nodes are not tightly calibrated. Previously, Meredith et al. (2011) demonstrated that divergence time estimates for many nodes in Placentalia are too old when calibrations are exclusively from taxa with larger body sizes and relatively slow rates of molecular evolution. Similarly, Meredith et al. (2011) showed that divergence time estimates are too young for clades with larger body sizes and slower rates of molecular evolution when calibrations are limited to taxa with smaller body sizes and faster rates of evolution. Meredith et al.'s (2011) strategy to mitigate against these problems was to employ a dense network of calibrations at 82 nodes including both shallow nodes, some of which subtend clades with larger-bodied taxa (e.g., Proboscidea, Cetacea, Hominoidea), and deeper nodes where ancestral body size was presumably smaller (e.g., Paenungulata, Cetartiodactyla, Haplorhini). Meredith et al. (2011) also noted that hard-bounded calibrations are more effective than soft-bounded calibrations in mitigating dates that are significantly younger than the fossil record.

By contrast with Meredith et al. (2011), Phillips (2016) preferred timetrees that underpin his conclusion that most interordinal cladogenesis occurred after the $\mathrm{KPg}$ boundary, are based on a much sparser set of calibrations for 27 nodes from dos Reis et al. (2012), with and without three new maximum bounds that were applied to rodents, primates, and bats. Phillips (2016) eschewed hard-bounded constraints and performed these analyses with soft-bounded constraints. Phillips (2016) argued that his interordinal divergence estimates are more accurate than previous studies because rate transference 
problems resulting from calibrations within large-bodied clades were mitigated.

However, Phillips (2016) paid less attention to potential problems that may arise when divergence times are too young in clades with larger body sizes and longer generation times. Timetree analyses with too few calibrations in large-bodied/long lifespan clades, as is the case with Phillips' (2016) original and augmented calibration sets from dos Reis et al. (2012), result in divergence time estimates for numerous clades that are younger than their minimum ages implied by the fossil record. We refer to these lineages as 'zombie' lineages (Fig. 1). By contrast with ghost lineages, which occur when a lineage is inferred to exist before it is represented in the fossil record, zombie lineages occur when the origin of a crown clade is estimated by molecular timetree methods to post-date the appearance of an older crown fossil (Fig. 1). This circumstance suggests that the fossil specimen should not have been alive at the age before its origin estimated by geochronological methods. In popular culture, fictional individuals that are not alive and yet have the appearance of being alive are commonly referred to as the undead or zombies.

Importantly, divergence times of deeper nodes on Phillips' preferred timetrees appear to be dragged forward owing to underestimation of divergence times in uncalibrated clades with larger body sizes and/or longer lifespans (Fig. 2, Table 2). Inspection of Phillips' (2016) timetree shows that at least 61 of 136 internal nodes in Placentalia have estimated ages that are younger than minimum ages implied by the fossil record (Fig. 2, Table 2). This list includes numerous superordinal clades as well as clades that are characterized by taxa with smaller body sizes and/or relatively short lifespans. For example, Phillips' (2016) estimated age for the superordinal clade Afrotheria is 57.7 Ma, which is younger than the minimum age for the oldest stem proboscidean (Eritherium, 59.2 Ma) (Gheerbrant, 2009; Schmitt and Gheerbrant, 2016; Kocsis et al., 2014). Indeed, the minimum age for Eritherium implies that the minimum ages for the superordinal clades Hyracoidea + Proboscidea, Paenungulata, and Afrotheria should all be at least 59.2 Ma, but Phillips estimated age for Hyracoidea + Proboscidea is only 44.6 Ma. Similarly, Phillips estimated ages for Fereuungulata (Carnivora + Pholidota + Perissodactyla + Cetartiodactyla) and Variamana (Fereuungulata + Chiroptera) are only 61.5 and 61.6 Ma, respectively, yet the oldest stem carnivorans are from the middle 
Puercan (65-64 Ma; Fox et al., 2010). Thus, Phillips' (2016) estimated divergence times for four superordinal clades in Laurasiatheria (Ostentoria, Zoomata, Fereuungulata, Variamana) are all younger than the oldest stem fossils for Carnivora (Fox et al., 2010). Phillips (2016) noted that analyses with Meredith et al.'s (2011) calibrations resulted in ghost lineages in Boreoeutheria that total more than one quarter of a billion years. However his own preferred timetree, with distorted divergence times that are in striking conflict with the fossil record (Fig. 2), results in zombie lineages that exceed half a billion years. Four of these zombie lineages exceed 20 million years and are shown in bold in Table 2. Ghost lineages are inferred to exist but have no fossil record, whereas zombie lineages are the opposite of ghost lineages and have known fossil records that are incompatible with errant timetree dates. Ghost lineages are an expected product of an incomplete fossil record, whereas zombie lineages are logically impossible except in cases where minimum ages for fossils are inaccurate or fossils have been attributed to the incorrect taxonomic group. However, the zombie lineages with some of the largest dating errors (e.g., Perissodactyla, Ceratomorpha, Cetacea) have minimum dates that are based on unambiguously assigned fossils (Table 2). Phillips' (2016) preferred timetrees, which are based on a relatively sparse compilation of 27 calibrated nodes (dos Reis et al., 2012) relative to Meredith et al.'s (2011) 82 highlight the point that timetree analyses should include calibrations at more nodes, rather than fewer nodes, to assist with rate-shift identification errors that can drag uncalibrated nodes both backward and forward in time. Dos Reis et al.'s (2012) 27 calibrations were appropriate for their phylogenomic data set with 37 mammalian species, but these calibrations are insufficient to calibrate Meredith et al.'s (2011) data set encompassing 164 mammals and five outgroups.

Even with its numerous zombie lineages that are in direct conflict with the fossil record, Phillips' (2016) timetree (Fig. 2) also retains a variety of ghost lineages that are older than the fossil record, albeit with smaller discrepancies than most other studies (Meredith et al., 2011; dos Reis et al., 2012; Slater, 2013). Some of the most prominent ghost lineages on Phillips' (2016) tree occur in clades with notoriously poor fossil records including Lemuriformes and Chiroptera. In the case of Lemuriformes, Phillips' (2016) estimate for the most recent common ancestor of this clade is $36.8 \mathrm{Ma}$, but the oldest fossils are only from the Holocene and are only 11.7 thousand years old 
(Paleobiology Database). Similarly, the chiropteran family Craseonycteridae (bumble bats) does not have a fossil record, but Phillips' age for the most recent common ancestor Craseonycteridae and Megadermatidae is $36.8 \mathrm{Ma}$ and implies a ghost lineage of this duration.

\subsection{Timetree analyses without larger-bodied and long lifespan taxa}

Timetree analyses with reduced taxon sampling (122 of 169 taxa from Meredith et al., 2011) are reported in Figure 3 and Table 3. Figure 3 shows the timetree based on autocorrelated rates with hard-bounded constraints. The results of four different analyses with different combinations of hard-bounded versus soft-bounded constraints and autocorrelated versus independent rates are shown in Table 3. Timetrees in nexus format are available at TreeBASE (http://purl.org/phylo/treebase/phylows/study/TB2:S19854). By contrast with Phillips (2016) analyses that retained large-bodied and long-lived taxa without calibrations, the results of our analyses recovered Cretaceous dates, including 95\% credibility intervals, for all interordinal divergences within Placentalia (Fig. 3, Table 3). These dates are younger than in Meredith et al.'s (2011) 169-taxon timetree, but are generally in good agreement with dos Reis et al.'s (2012) estimated dates that firmly support the long fuse model (Fig. 3, Table 3). For example, Meredith et al.'s (2011, table S6) mean date for Placentalia is $101.4 \mathrm{Ma}$, whereas our date for this clade based on analyses with 122 taxa is $\sim 92.0$ Ma (Table 3). Similarly, dos Reis et al. (2012, table 1) obtained a mean date of 90.9 Ma for Placentalia based on four different analyses. By contrast, our estimated divergence dates for interordinal divergences are in direct conflict with Phillips' (2016) soft explosive model. Importantly, the soft explosive model of diversification is contradicted if interordinal divergences within Afrotheria, Laurasiatheria, and Euarchontoglires pre-date the KPg by even a small amount of time (e.g., 100,000 years), let alone several million or even tens of millions of years, because pre-KPg divergences preclude a role for the KPg in promoting interordinal diversification. In this context, O'Leary et al. (2013) suggested that the early Paleocene Protungulatum donnae (64.85 Ma) is well nested inside of Laurasiatheria. However, Archibald et al. (2011) reported a new species of Protungulatum from Late Cretaceous rocks in Montana 
that are at least 300,000 years older than the KPg extinction that resulted in the final extirpation of non-avian dinosaurs. If Protungulatum is a crown laurasiatherian, then several interordinal divergences in Laurasiatheria are immediately pushed back into the Cretaceous in direct conflict with both the explosive and soft explosive models.

\subsection{Body size and lifespan in ancestral placental mammals}

Phillips (2016) assumed that all Cretaceous eutherians were small $(<500 \mathrm{~g})$ insectivores or omnivores based on existing paleontological evidence (e.g., O'Leary et al., 2013). However, fossils do not provide conclusive evidence regarding the ancestry of extant mammals because it is not straightforward to link Cretaceous and Paleocene fossils to modern placental lineages (Romiguier et al., 2013). By contrast with Phillips (2016), Romiguier et al. (2013) estimated body size and life span in early placental mammals based on ancestral reconstructions of two aspects of genome dynamics, GC content and $\mathrm{dN} / \mathrm{dS}$ ratio, which are correlated with life history traits. Romiguier et al. (2013) estimated that early placental mammals had life spans $>25$ years and body masses $>1$ $\mathrm{kg}$. These estimates are more similar to most primate, cetartiodactyl, and carnivoran species than to smaller and shorter-lived mice and shrews (Romiguier et al., 2013). Romiguier et al.'s (2013) results reinforce the important point that rate-shift identifiability errors may push and pull in both directions depending on which nodes are calibrated. Indeed, Phillip's (2016) preferred timetree presents many intraordinal divergences that may drag forward interordinal divergences because they are younger than minimum dates implied by the fossil record (Fig. 2, Table 2). Some of the most striking differences include Whippomorpha, Cetacea, Odontoceti, Mysticeti, Perissodactyla, Ceratomorpha, Pinnipedia, Otariidae + Odobenidae, Anthropoidea, Catarrhini, Platyrrhini, Hominoidea, Prooscidea, and Sirenia (Fig. 2, Table 2).

\subsection{Divergence times, morphological cladistics, and the fossil record}

Phillips (2016) suggests that there is a perplexing mismatch between the diversification pulse identified by Meredith et al. (2011) at $~ 83 \mathrm{Ma}$ and the absence of 
such a pulse in the fossil record because eutherian species richness is virtually unchanged in Campanian fossil faunas ( 84-71 Ma) and only one new family appears during this interval. We disagree with this conclusion based on our analysis of the eutherian fossil record in the Cretaceous (see section 3.5). Also, Halliday and Goswami's (2016) analysis of morphological diversity suggests that eutherians showed an increase in morphological disparity in the Campanian. At the same time, the pulse of diversification suggested by Meredith et al.'s (2011) analyses allows for, but does not require, the emergence of multiple orders and families appearing in the fossil record during this time. Rather, some or all of the emergent lineages with living descendants may have remained morphologically similar to each other until after the KPg boundary when morphological diversification occurred in the wake of the KPg extinction. Further, Meredith et al.'s (2011) analyses were based on a pure birth model and only queried patterns of diversification in the ancestry of extant Placentalia, not all of Eutheria as implied by Phillips.

Meredith et al.'s (2011) finding that the ancestors of extant placental mammals did not experience a significantly increased diversification rate after the KPg mass extinction does not imply that the same is also true for the entirety of Placentalia, which includes extinct placental lineages (e.g., Purgatorius, creodonts) that left no descendants. Finally, Phillips (2016) incorrectly suggests "Meredith et al.'s (2011) molecular diversification analyses instead suggest a decline across the KPg and throughout the Paleocene." Meredith et al.'s (2011) diversification analyses with both TreePar and Laser, which were performed to identify the locations of temporal shifts in the diversification rate of mammalian lineages with extant descendants, failed to show any significant shifts in diversification rates at or near the KPg boundary.

Phillips (2016) acknowledges that palaeontologists have recovered Cretaceous zhelestids and zalambdalestids within crown Placentalia (Archibald, 1996; Archibald et al., 2001), but then suggests that this argument for ancient placental origins is invalid because both zhelestids and zalambdalestids have been recovered as stem eutherians in more recent cladistic analyses (Wible et al., 2009; Zhou et al., 2013). These arguments ignore many problems with morphological cladistic analyses for recovering higher-level relationships among eutherian mammals (Springer et al., 2007a, 2008, 2013). The most 
comprehensive phenomic data sets that are available for diverse fossil and living mammals are those of O'Leary et al. (2013), which comprises 4541 phenomic characters for 86 fossil and living mammals, and Halliday et al. (2015), which includes 680 morphological characters for 177 fossil and extant taxa. Phylogenetic analyses with O'Leary et al.'s (2013) phenomic data set are in striking disagreement with analyses based on molecular data. Instead of recovering extensively validated molecular clades such as Afrotheria, Afrosoricida, Paenungulata, Boreoeutheria, Laurasiatheria, and Eulipotyphla, O'Leary et al.'s (2013) phenomic tree provides robust support for a wide range of polyphyletic taxa including an "insectivore" group, a "spiny hedgehog" group, and "ant and termite eating" group, a "tree dwelling" group, an "ungulate" group, and a “cud chewing” group (Springer et al., 2013). These results are not surprising given that the global theater for mammalian evolution includes similar habitats in far-flung regions of Earth that promoted the evolution of remarkable ecomorphological convergence (Springer et al., 2013). Similarly, Halliday et al.'s (2015) morphological tree exhibits numerous instances of polyphyletic groups that conflict with well-supported molecular clades or extant mammalian orders with living and fossil representatives, including Afrotheria, Paenungulata, Macroscelidea, Boreoeutheria, Laurasiatheria, Variamana, Eulipotyphla, Talpidae, Ostentoria, Euarchontoglires, and Scandentia. While some of the problems with ecomorphological convergence for living taxa may be overcome with combined analyses that include large molecular data sets, or by enforcing molecular scaffolds, these approaches may not be adequate for accurately placing extinct taxa that lack molecular data (see below). A related problem is that few coded anatomical characters are available for extant mammals in comparison to fossil mammals (Guillerme and Cooper, 2016). This issue may compromise the accuracy of morphological cladistic analyses with mammalian data sets that include both fossils and living taxa

Phillips (2016) cited two studies in support of his conclusion that hypotheses of Cretaceous placental origins are invalid: Wible et al. (2009) and Zhou et al. (2013). Wible et al.'s (2009) analyses were based on a data matrix comprised of 69 taxa and 408 characters, including 11 extant placentals with three genera (Chaetophractus, Bradypus, Tamandua) in Xenarthra, four (Orycteropus, Rhynchocyon, Procavia, Potamogale) in Afrotheria, one (Ptilocercus) in Euarchontoglires, and three (Blarina, Sorex, Solenodon) 
in Laurasiatheria. Major problems with the phylogenetic placement of extant taxa on Wible et al.'s (2009) tree include Afrotheria polyphyly, Eulipotyphla paraphyly, and Boreoeutheria paraphyly. Moreover, taxa that are traditionally regarded as stem carnivorans (Vulpavus, Miacis) and a stem "artiodactyl" (Gujaratia = Diacodexis) fall outside of crown Placentalia (mislabeled on Wible et al.'s [2009] tree). In addition, many of the clades on Wible et al.'s (2009) tree have low support scores (e.g., decay index for Placentalia $=1$ step). It is more costly to enforce a well-supported molecular scaffold (Afrotheria, Xenarthra, (Laurasiatheria, Euarchontoglires)) with Wible et al.'s (2009) data (+26 steps, six trees) than it is to constrain a sister-group relationship between Glires and Cretaceous zalambdalestids ( +25 steps, six trees). Templeton and winning-sites tests reject all six trees with the molecular scaffold, whereas only four of six trees with zalambdalestids + Glires are rejected by one or both tests (Table 4). Given these results it is difficult to argue, as Phillips (2016) has done, that Cretaceous eutherians are definitively excluded from crown Placentalia.

Zhou et al.'s (2013) analyses included ten extant placentals: three genera in Laurasiatheria (Erinaceus, Felis, Canis), two in Euarchontoglires (Rattus, Oryctolagus), and five in Xenarthra (Bradypus, Tamandua, Dasypus, Chaetophractus, Euphractus). Of these, Erinaceus was recovered as the sister taxon to all remaining placental genera. Zhou et al.'s (2013) morphological tree is in conflict with the monophyly of Laurasiatheria and Boreoeutheria, which are among the most robust superordinal clades of placental mammals based on analyses with diverse molecular and phylogenomic data (e.g., Madsen et al., 2001; Murphy et al., 2001a,b; Springer et al., 2004, 2005, 2007a,b; Wildman et al., 2007; Nishihara et al., 2009; Meredith et al., 2011; Romiguier et al., 2013; Tarver et al., 2016). Following Phillips' (2016) logic do the results of Wible et al. (2009) and Zhou et al. (2013) invalidate Afrotheria, Laurasiatheria, Eulipotyphla, and Boreoeutheria? Is Gujaratia, with its "double trochleated astragalus" that is diagnostic for "artiodactyls", outside of crown Placentalia? Are Vulpavus and Miacis, with their carnassial teeth that are diagnostic of Carnivora, outside of crown Placentalia? We suggest that the answer to these rhetorical questions is no, and that morphological cladistic analyses remain problematic for higher-level mammalian relationships because of rampant ecomorphological convergence, diachronous terminals that create opportunities for long- 
branch misplacement, and missing data problems (Springer et al., 2007a, 2008, 2013; Fig. 4). Specifically, random homoplasy on long branches leading to extant taxa ("the pull of the Recent") may create a morphological analog of the long-branch problem with molecular data so that increased homoplasy on extant tips may mislead phylogenetic analyses that include both extant and extinct taxa (Wang et al., 2005). Homoplasy resulting from parallel evolutionary constraints will be more severe than garden-variety long-branch misplacement because parallel evolutionary constraints can result in correlated homoplasy that affects multiple characters (e.g., characters related to eating ants and termites; Fig. 4). Homoplasy resulting from parallel evolutionary constraints (e.g., on functional anatomy) has previously been suggested as the cause of anomalous phylogenetic relationships for carnivorans (Wang et al. 2005: Finarelli 2008) and rodents (Rodrigues et al. 2011, Lazzari et al. 2008).

Potential problems with morphological cladistic analyses of higher-level relationships among placental mammals have also been demonstrated in pseudoextinction analyses with combined supermatrices (i.e., molecules and morphology) that queried the phylogenetic position of extant orders of placental mammals after recoding molecular data as missing (Springer et al., 2007a). For example, when odd-toed ungulates (Order Perissodactyla) were treated as extinct they clustered inside of Afrotheria as the sister to Hyracoidea. Similarly, when aardvarks (Order Tubulidentata) and pangolins (Order Pholidota) were recoded as extinct these orders were allied with Xenarthra rather than placed within Afrotheria and Laurasiatheria, respectively. Carnivorans, in turn, were recovered as the sister taxon to all other placental mammals when recoded as extinct. These results are difficult to reconcile with the results of molecular data, but are nevertheless the best-supported hypothesis in pseudoextinction analyses (Springer et al., 2007a).

Along these lines, Sansom and Wills (2013) showed that the inevitable bias of the fossil record to preserve biomineralized (hard) morphological characters systematically distorts phylogeny. Specifically, this bias results in 'stemward slippage' so that fossils are significantly more likely to move towards the root of the tree than away from the root. The net result of stemward slippage is that fossils will be artificially deployed to deeper branches on the tree, in some cases below the crown clade to which they belong, so that 
divergence dates will be underestimated (Sansom and Wills, 2013). Given this suite of concerns (i.e., parallel evolutionary constraints, long versus short branches on trees with diachronous terminals, incomplete fossil specimens, results of pseudoextinction analyses, stemward slippage with biomineralized characters), we strongly disagree with Phillips' (2016) conclusion that cladistic analyses and the fossil record invalidate the inclusion of Cretaceous eutherians inside of crown Placentalia. Instead, we suggest that the apparent conflict between molecular and paleontological dates for the placental mammal radiation may result from systematically distorted morphology-based phylogenies for fossil and extant taxa, and do not discount the possibility that 85-90 Ma zalambdalestids or other Cretaceous forms are crown rather than stem eutherians. If even a handful of Cretaceous eutherians have been inaccurately placed outside Placentalia in morphological cladistic analyses because of the abovementioned problems, then there is effectively no disagreement between the fossil record and molecular timetrees with Cretaceous interordinal divergences.

\subsection{Molecular timetree diversification patterns and the fossil record}

To undergird his argument in favor of tightening maximum calibrations to mitigate against upward rate transference problems, Phillips (2016) demonstrated that his preferred timetree (dR27b), based on updated calibrations from dos Reis et al. (2012), places most interordinal cladogenic events in the species rich Paleocene. By contrast, the more heavily calibrated Mer82c tree positions most of these cladogenic events in the far less speciose Campanian-Maastrichtian (Late Cretaceous). This is taken by Phillips (2016) as evidence that the $\mathrm{dR} 27 \mathrm{~b}$ tree better fits the diversification of fossil placental mammals documented in the wake of the KPg mass extinction. This assumption is unwarranted, primarily because interordinal diversification need not take place in the Paleocene to be consistent with the fossil record, as the spike in Paleocene diversity may have been driven by intraordinal diversification instead. What is more pertinent to Phillips' (2016) hypothesis is whether or not the timetree of interest records an increase in the rate of new lineages in the earliest Paleocene relative to the latest Cretaceous. 
When examining eutherian fossil diversity in the Paleobiology Database, we found that the Danian (66.0-61.6 Ma) records an upsurge in the accumulation of new lineages: 29 new families, 128 new genera and 248 new species compared to just two, 13 and 20, respectively, in the Maastrichtian (Fig. 5A, Supplementary Fig. 1). This corresponds to respective rates of 6.59,29.09 and 56.36 new lineages per million years (NL/Myr), resulting in $+1910 \%,+1265 \%$ and $+1619 \%$ rate increases. These rate increases represent the largest for each taxon category in every stage we examined (Cretaceous-Eocene), testifying to the magnitude of the post-KPg diversification event on eutherian diversity. We found that the Mer82c tree recorded a very slight rate decrease from the Maastrichtian to the Danian (-0.65\%), whereas the $\mathrm{dR} 27 \mathrm{~b}$ tree showed a rate increase (15.91\%), suggesting that Phillips' preferred timetree matches the K/Pg event better than the former (Fig. 5B, Supplementary Fig. 1). However, Mer82c records a greater number of new lineages (six versus four) in the Danian, and therefore implies a higher rate for the accumulation of new lineages than dR27b (1.36 vs. $0.91 \mathrm{NL} / \mathrm{Myr})$. Furthermore, dR27b's greatest rate increase (+237\%) occurs in the Maastrichtian (72.166.0 Ma), immediately prior to the KPg boundary. We also evaluated a timetree (Emer15) reported by Emerling et al. (2015), which included more species (388) and updated calibrations relative to Meredith et al. (2011). Like dR27b, Emer15 records a greater number of new lineages in the Danian compared to the Maastricthian, but the number of new lineages (seven), rate (1.59 NL/Myr), and rate increase $(+61.7 \%)$ are all higher than dR27b (Fig. 5B). This is despite the fact that Emer15 records all but one placental interordinal cladogenic event prior to the KPg boundary, consistent with the long fuse model.

Among the different timetrees that we examined, dR27b (2010 Geological Timescale [GT]; KPg = 65.5 Ma) records only one new lineage (at $64.58 \mathrm{Ma}$ ) during the 1-million year interval after the KPg boundary, and no further speciation events until the end of the Danian when there are three cladogenic events between 61.6 and 61.22 Ma. However, there are four new lineages in the 2-million year interval prior to the $\mathrm{KPg}$ boundary (67.56-65.58 Ma), following a cladogenic drought of 4.7 million years. Similarly, Mer82c (2010 GT) records six cladogenic events in the 2-million year interval preceding the KPg boundary (67.5-65.54 Ma) following 3.6 million years of no 
cladogenesis, and a further six at the end of the Danian (61.99-61.22 Ma). Notably, both timetrees show qualitatively similar patterns near the KPg boundary, although preSelandian cladogenic events for $\mathrm{dR} 27 \mathrm{~b}$ are interordinal, whereas Mer82c records numerous intraordinal cladogenic events during the same time period. Compared to Mer82c and dR27b, Emer15 (2014 GT; KPg = 66 Ma) appears to provide the best fit to a model of placental diversification in the immediate wake of the KPg extinction event. After four million years of no new crown placentals, a new lineage appears at $67 \mathrm{Ma}$ and two speciation events occur immediately before the KPg between 66.13 and 66.04 Ma. Subsequently there is a relatively steady accumulation of additional lineages (seven) during the Danian. Similar to Mer82c, many of these cladogenic events reflect intraordinal rather interordinal diversification. Together, these results suggest that placental interordinal cladogenesis in the Cretaceous and an increased accumulation of placental lineages following the KPg boundary need not be mutually exclusive.

A second and related contention of Phillips (2016) concerns the long fuse model's placement of many of the placental interordinal cladogenic events in the Campanian. Indeed, both Mer82c and Emer15 record numerous speciation events during the Campanian, with 15 and 12 new lineages, respectively, compared with only three and one in the previous stage. While the long timespan of the stage may partially explain this pattern (11.5 myr 2014 GT, 12.9 myr 2010 GT), Emer15 still records a large rate increase $(+182 \%)$ (Fig. 5B) after correcting for stage duration. Even Phillips' (2016) preferred timetree $(\mathrm{dR} 27 \mathrm{~b})$ estimates that the first three crown placental cladogenic events occurred during the Campanian. Phillips (2016) states that this "most profound" diversification event (in the Campanian) inferred by the molecular consensus "leaves no trace in the fossil record" as "eutherian species richness is virtually unchanged" in this stage. Contrary to Phillips (2016), the Paleobiology Database indicates that this stage had the highest number of new families (four), genera (16) and species (21) in the Cretaceous. The previous stage, the Santonian, had zero new families and genera and one new species, with a standing diversity of only two families, one genus and two species. Prior to that, the Coniacian records no new families and only three new genera and species. Among 15 stages (Aptian-Priabonian), the Campanian increase in the rate of new species accumulation $(+393 \%)$ was third highest, behind only the Turonian $(+865 \%)$ and the 
Danian (+1619\%). While not as remarkable as the Danian, Campanian diversification was relatively extensive and may be associated with interordinal diversification in Placentalia if morphological cladistic analyses have misplaced some Cretaceous eutherians outside of crown Placentalia, as argued above. In this context, Halliday and Goswami (2016) utilized a set of morphology-based timetrees to estimate the change in eutherian morphological disparity through time. Despite using trees that assumed an origin for Placentalia near the KPg boundary, Halliday and Goswami (2016) consistently recovered an increase in eutherian morphospace during the Campanian, which had the highest disparity estimates during the entirety of the Cretaceous. Stemward slippage and other problems with cladistic analyses (e.g., diachronous terminals), coupled with morphometric analyses of Mesozoic mammals and mammaliaforms (e.g., Chen and Luo, 2013; Gill et al., 2014; Halliday and Goswami, 2016), suggest that Campanian placentals with diverse specializations may be hidden in plain sight, or perhaps will be uncovered with more extensive sampling (e.g., Luo et al., 2007).

\subsection{Conclusions}

The soft explosive model (Phillips, 2016) was proposed as a solution to the longstanding debate over the timing of placental mammal diversification. Unlike the long fuse model, which posits all or most interordinal diversification in the Cretaceous, followed by most intraordinal diversification after the KPg mass extinction, the soft explosive model positions most interordinal and all intraordinal diversification after the

KPg mass extinction. Meredith et al. (2011) suggested that timetree analyses should include more calibrations, rather than fewer, because lineage-specific rate variation can result in misleading divergence times when fossil calibrations are sparsely or unevenly distributed throughout the tree and are limited to taxa with either fast or slow rates of molecular evolution. Phillips (2016) addressed rate transference problems in Placentalia by omitting calibrations in most clades with large body size and/or long lifespan, and recovered most interordinal divergences after the KPg boundary. However, Phillips' (2016) soft explosive model results in more than 500 million years of zombie lineages, which occur when estimated divergence dates are younger than reliable minimum ages 
that are implied by crown fossils. Importantly, Phillips' (2016) interordinal divergence dates are dragged forward by divergence dates in clades with large body size and/or long lifespan that are too young. Zombie lineages are not unique to Phillips' (2016) study. For example, Sato et al. (2016) obtained a date of 58.6 Ma for the most recent common ancestor of Eulipotyphla (hedgehogs, moles, shrews, solenodons), but this date is younger than the oldest erinaceid (hedgehog) fossil (Benton et al., 2015).

By contrast with Phillips (2016), we employed an alternate approach to the rate transference problem (Springer et al., 2003) and deleted taxa with large body size and/or long lifespan, and recovered all placental interordinal divergences in the Cretaceous. These results are in good agreement with other recent timetree studies that support the long fuse model of placental mammal diversification (dos Reis et al., 2012; Emerling et al., 2015; Tarver et al., 2016). Potential problems with morphological cladistic analyses of higher-level relationships among placental mammals, including inaccurate phylogenies, stemward slippage, and the "pull of the Recent", may account for the perceived discrepancies between molecular and paleontological estimates for the timing of placental diversification.

\section{Acknowledgments}

This work was supported by NSF grant DEB-1457735 (M.S.S.). We thank J. Gatesy, E. Teeling, T. Guillerme, and an anonymous reviewer for helpful comments on earlier drafts of this manuscript. M. Phillips kindly supplied his timetrees. Paintings were provided by C. Buell. 


\section{References}

Anderson, D., 2008 Ischyromyidae. In: Janis, C.M., Gunnell, G.F., Uhen, M.D. (Eds.), Evolution of Tertiary mammals of North America, volume 2. Cambridge University Press, New York, NY, pp. 311-325.

Antoine, P.-O., Salas-Gismondi, R., Baby, P., Benammi, M., Brusset, S., de Franceshi, D., Espurt, N., Goillot, C., Pujos, F., Tejada, J., Urbina, M., 2007 The middle Miocene (Laventan) Fitzcarrald Fauna, Amazonian Peru. In: Díaz-Martínez, E., Rábano, I., 4th European Meeting on the Palaeontology and Stratigraphy of Latin America. Cuadernos del Museo Geominero, $n^{\circ}$ 8, Instituto Geológico y Minero de España, Madrid, Spain, pp. $19-24$.

Antoine, P.-O., Marivaux, L., Croft, D.A., Billet, G., Ganerød, Jaramillo, C., Martin, T., Orliac, M.J., Tejada, J., Altamirano, A.J., Duranthon, F., Fanjat, G., Rousse, S., Gismondi, R.S., 2011 Middle Eocene rodents from Peruvian Amazonia reveal the pattern and timing of caviomorph origins and biogeography. Proc. Roy. Soc. B 279, 1319-1326.

Archibald, J.D., Deutschman, D.H., 2001. Quantitative analysis of the timing of the origin and diversification of extant placental orders. J. Mamm. Evol. 8, 107-124.

Archibald, J.D., Zhang, Y., Harper, T., Cifelli, R.L., 2011. Protungulatum, confirmed Cretaceous occurrence of an otherwise Paleocene eutherian (placental?) mammal. J. Mamm. Evol. 18, 153-161.

Avery, D.M., 2001. The Plio-Pleistocene vegetation and climate of Sterkfontein and Swartkrans, South Africa, based on micromammals. J. Hum. Evol. 41, 113-132.

Banyue, W., Zhanxiang, Q., 2003 Notes on early Oligocene ursids (Carnivora, Mammalia) from Saint Jacques, Nei Mongol, China. Bull. Am. Mus. Nat. Hist. 279, 116124. 
Barnes, L.G., 1976. Outline of Eastern North Pacific fossil cetacean assemblages. Syst. Zool. 25, 321-343.

Barnes, L.G., 2002. An early Miocene long-snouted marine platanistid dolphin (Mammalia, Cetacea, Odontoceti) from the Korneuburg Basin (Austria). Beitr. Paläont. 27, 407-418.

Beard, K.C., Qi, T., Dawson, M.R., Wang, B., Li, C., 1994 A diverse new primate fauna from middle Eocene fissure-fillings in southeastern China. Nature 368, 604-609.

Benton MJ, Donoghue PCJ. 2007 Paleontological evidence to date the tree of life. Mol. Biol. Evol. 24, 26-53.

Benton, M.J., Donoghue, P.C.J., Asher, R.J., 2009. Calibrating and constraining molecular clocks. In: Hedges, S.B., Kumar, S. (Eds.), The Timetree of Life. Oxford University Press, New York, NY, pp. 35-86.

Benton, M.J., Donoghue, P.C.J., Asher, R.J., Friedman, M., Near, T.J., Vinther, J., 2015. Constraints on the timescale of animal evolutionary history. Palaeontologia Electronica 1811FC, 1-107.

Bergqvist, L.P., Abrantes, É.A.L., Avilla, L. dos S., 2004. The Xenarthra (Mammalia) of Sãn José de Itaboraí Basin (Upper Paleocene, Itaboraian), Rio de Janeiro, Brazil. Geodiversitas 26, 323-337.

Bi S, Wang Y, Guan J, Sheng X, Meng J. 2014. Three new Jurassic euharamiyidan species reinforce early divergence of mammals. Nature 514, 579-584.

Bianucci, G., Landini, W., 2006. Killer sperm whale: a new basal physeteroid (Mammalia, Cetacea) from the Late Miocene of Italy. Zool. J. Linn. Soc. 148, 103-131. 
Bininda-Emonds, O.R.P., Cardillo, M., Jones, K.E., MacPhee, R.D.E, Beck, R.M.D., Grenyer, R., Price, S.A., Vos, R.A., Gittleman, J.L., Purvis, A., 2007. The delayed rise of present-day mammals. Nature 446, 507-512.

Bloch, J.I., Silcox, M.T., Boyer, D.M., Sargis, E.J., 2007. New Paleocene skeletons and the relationship of plesiadapiforms to crown-clade primates. Proc. Natl. Acad. Sci. USA 104, 1159-1164.

Boessenecker, R.W., Churchill, M., 2015. The oldest known fur seal. Biol. Lett. 11, 20140835.

Boessenecker, R.W., Fordyce, R.E., 2015. A new genus and species of eomysticetid (Cetacea: Mysticeti) and a reinterpretation of “Mauicetus" lophocephalus Marples, 1956: transitional baleen whales from the upper Oligocene of New Zealand. Zool. J. Linn. Soc. $175,607-660$.

Campbell, K.E. Jr, Frailey, C.D., Romero-Pittman, L., 2004. The Paleogene Santa Rosa Local Fauna of Amazonian Perú: geographic and geologic setting. Nat. Hist. Mus. Los Angeles County, Sci. Ser. 40, 3-14.

Cohen, K.M., Finney, S.C., Gibbard, P.L., Fan, J.-X., 2013 (updated). The ICS International Chronostratigraphic Chart. Episodes 36, 199-204.

Cozzuol, M.A., 2006. The Acre vertebrate fauna: age, diversity, and geography. J. So. Amer. Earth Sci. 21, 185-203.

Czaplewski, N.J., Morgan, G.S., McLeod, S.A., 2008. Chiroptera. In: Janis, C.M., Gunnell, G.F., Uhen, M.D. (Eds.), Evolution of Tertiary mammals of North America, volume 2. Cambridge University Press, New York, NY, pp. 174-197. 
Case, J.A., Meredith, R.W., Person, J., 2009. A pre-Neogene phalangerid possum from South Australia. Mus. No. Ariz. Bull. 65, 659-675.

Chen, M., Luo, Z.X., 2013. Postcranial skeleton of the Cretaceous mammal Akidolestes cifellii and Its locomotor adaptations. J. Mamm. Evol. 20, 159-189.

Chester, S.G.B., Bloch, J.I., Boyer, D.M., Clemens, W.A., 2015. Oldest known euarchontan tarsals and affinities of Paleocene Purgatorius to Primates. Proc. Natl. Acad. Sci. USA 112, 1487-1492.

Czaplewski, N.J., Morgan, G.S., McLeod, S.A., 2008. Chiroptera. In: Janis, C.M., Gunnell, G.F., Uhen, M.D. (Eds.), Evolution of Tertiary Mammals of North America, volume 2. Cambridge University Press, New York, NY, pp. 174-197.

Dawson, M.R., Marivaux, L., Li, C., Beard, K.C., Métais, G., 2006. Laonastes and the "Lazarus Effect" in Recent mammals. Science 311, 1456-1458.

Delsuc, F., Vizcaino, S.F., Douzery, E.J.P., 2004. Influence of Tertiary paleoenvironmental changes on the diversification of South American mammals: a relaxed molecular clock study with xenarthrans. BMC Evol. Biol. 4, 11.

Deméré, T.A., Berta, A., Adam, P.J., 2003. Pinnipedimorph evolutionary biogeography. Bull. Am. Mus. Nat. Hist. 279, 32-76.

dos Reis, M., Inoue, J., Hasegawa, M., Asher, R.J., Donoghue, P.C.J., Yang, Z., 2012. Phylogenomic datasets provide both precision and accuracy in estimating the timescale of placental mammal phylogeny. Proc. R. Soc. B 279, 3491-3500.

Drake, R.E., Van Couvering J.A., Pickford, M., Curtis, G.H., Harris, J.A., 1988. New chronology for the early Miocene mammalian faunas of Kisingiri, western Kenya. J. Geol. Soc. Lond. 145, 479-491. 
Eiting, P., Gunnell, G.F., 2009. Global completeness of the bat fossil record. J. Mamm. Evol. 16, 151-173.

Emerling, C.A., Huynh, H.T., Nguyen, M.A., Meredith, R.W., Springer, M.S., 2015. Spectral shifts of mammalian ultraviolet-sensitive pigments (short wavelength-sensitive opsin 1) are associated with eye length and photic niche evolution. Proc. Roy. Soc. B $282,20151817$.

Finarelli, J.A., 2008. A total evidence phylogeny of the Arctoidea (Carnivora: Mammalia): relationships among basal taxa J. Mamm. Evol. 15, 231-259.

Finarelli, J.A., Clyde, W.C., 2004. Reassessing hominoid phylogeny: evaluating congruence in the morphological and temporal data. Paleobiology 30, 614-651.

Flynn, J.J., Swisher, C.C. III, 1995. Cenozoic South American Land Mammal Ages: correlation to global geochronologies. In: Berggren, W.A., Kent, D.V., Hardenbol, J. (Eds.), Geochronology, Time-scales, and Global Stratigraphic Correlation, SEPM. Society for Sedimentary Geology, Special Publication 54, Tulsa, Oklahoma, pp. 317-333.

Flynn, J.J., Wyss, A.R., 1998. Recent advances in South American mammalian paleontology. Trends Ecol. Evol. 13, 449-454.

Flynn, L.J., Jacobs, L.L., 2008a. Aplodontoidea. In: Janis, C.M., Gunnell, G.F., Uhen, M.D. (Eds.), Evolution of Tertiary Mammals of North America, volume 2. Cambridge University Press, New York, NY, pp. 377-390.

Flynn, L.J., Jacobs, L.L., 2008b. Castoroidea. In: Janis, C.M., Gunnell, G.F., Uhen, M.D. (Eds.), Evolution of Tertiary Mammals of North America, volume 2. Cambridge University Press, New York, NY, pp. 391-405. 
Flynn, L.J., Lindsay, E.H., Martin, R.A., 2008. Geomorpha. In: Janis, C.M., Gunnell, G.F., Uhen, M.D. (Eds.), Evolution of Tertiary Mammals of North America, volume 2. Cambridge University Press, New York, NY, pp. 428-455.

Fordyce, R.E., 2005. A new specimen of archaic baleen whale Mauicetus parki (Late Oligocene, New Zealand) elucidates early crown-Mysticeti. J. Vertebr. Paleontol. 25, $58 \mathrm{~A}$.

Foley, N.M., Springer, M.S., Teeling, E.C., 2016. Mammal madness: is the mammal tree of life not yet resolved? Phil. Trans. R. Soc. B 371, 20150140.

Fox, R.C., Scott, C.S., Rankin, B.D., 2010. New early carnivoran specimens from the Puercan (earliest Paleocene) of Saskatchewan, Canada. J. Paleontol. 84, 1035-1039

Frailey, C.D., Campbell, K.E. Jr., 2004. Paleogene rodents from Amazonian Peru: the Santa Rosa Local Fauna. Nat. Hist. Mus. Los Angeles County, Sci. Ser. 40, 71-130.

Gheerbrant, E., 2009. Paleocene emergence of elephant relatives and the rapid radiation of African ungulates. Proc. Natl. Acad. Sci. USA 106, 10717-10721.

Gill, P.G., Purnell, M. a., Crumpton, N., Brown, K.R., Gostling, N.J., Stampanoni, M., Rayfield, E.J., 2014. Dietary specializations and diversity in feeding ecology of the earliest stem mammals. Nature 512, 303-305.

Godthelp, H., Archer, M., Cifelli, R., Hand, S.J., Gilkeson, C.F., 1992. Earliest known Australian Tertiary mammal fauna. Nature 356, 514-516.

Goin, F.J., Candela, A.M., Abello, M.A., Oliveira, E.V., 2009. Earliest South American paucituberculatans and their significance in the understanding of 'pseudodiprotodont' marsupial radiations. Zool. J. Linn. Soc. 155, 867-884. 
Goin, F.J., Sánchez-Villagra, M.R., Abello, A., Kay, R.F., 2007 A new generalized paucituberculatan marsupial from the Oligocene of Bolivia and the origin of 'shrew-like' opossums. Palaeontology 50, 1267-1276.

Gol'din, P.E., Marareskul, V.A., 2013. Miocene toothed whales (Cetacea, Odontoceti) from the Dniester Valley: the first record of sperm whales (Physeteroidea) from the Eastern Europe. Vestnik Zoologii 45, 21-26.

Guillerme, T., Cooper, N., 2016. Assessment of available anatomical characters for linking living mammals to fossil taxa in phylogenetic analyses. Biol. Lett. 12, 20151003.

Gunnell, G.F., Simmons, N.B., 2005. Fossil evidence and the origin of bats. J. Mamm. Evol. 12, 209-246.

Gutstein, C.S., Cozzuol, M.A., Pyenson, N.D., 2014. The antiquity of riverine adaptations in Iniidae (Cetacea, Odontoceti) documented by a humerus from the late Miocene of the Ituzaingó Formation, Argentina. Anat. Rec. 297, 1096-1102.

Halliday, T.J.D., Goswami, A., 2016. Eutherian morphological disparity across the endCretaceous mass extinction. Biol. J. Linn. Soc. 118, 152-168.

Halliday, T.J.D., Upchurch, P., Goswami, A., 2015. Resolving the relationships of Paleocene placental mammals. Biol. Rev. doi: 10.1111/brv.12242.

Harrison, T., Andrews, P., 2009. The anatomy and systematic position of the early Miocene proconsulid from Meswa Bridge, Kenya. J. Hum. Evol. 56, 479-496.

Hartenberger, J-L., 1998. Description de la radiation des Rodentia (Mammalia) du Paléocène supérieur au Miocène; incidences phylogénétiques. C. R. Acad. Sci. Paris Earth Planet. Sci. 326, 439-444. 
Hasegawa, M., Thorne, J.T., Kishino, H., 2003. Time scale of eutherian evolution estimated without assuming a constant rate of molecular evolution. Genes Genet. Syst. 78, 267-283.

Holliday, J.A., 2007. Phylogeny and Character Change in the Felid Carnivora. Unpublished Ph.D. Dissertation. Florida: College of Arts and Sciences, The Florida State University.

Horovitz, I., Martin, T., Bloch, J., Ladevèze, S., Kurz, C., Sánchez-Villagra, M.R., 2009. Cranial anatomy of the earliest marsupials and the origin of opossums. PLoS ONE 4, e8278.

Hunt, R.M. Jr., 1998. Evolution of the aeluroid Carnivora: diversity of the earliest aeluroids from Eurasia (Quercy, Hsanda-Gol) and the origin of felids. Am. Mus. Novitat. $3252,1-65$.

Janis, C.M., Theodor, J.M., 2015. Cranial and postcranial morphological data in rumionant phylogenetics. Zitteliana 32, 15-31.

Janis, C.M., Dawson, M.R., Flynn, L.J., 2008. Glires summary. In: Janis, C.M., Gunnell, G.F., Uhen, M.D. (Eds.), Evolution of Tertiary Mammals of North America, volume 2. Cambridge University Press, New York, NY, pp. 263-292.

Johnson, W.E., Eizirik, E., Pecon-Slattery, J., Murphy, W.J., Antunes, A., Teeling, E., O'Brien, S.J., 2006. The late Miocene radiation of modern Felidae: a genetic assessment. Science 311, 73-77.

Jones, K. E., Bielby, J., Cardillo, M., Fritz, S. A., O’Dell, J., Orme, C. D. L., Safi, K., Sechrest, W., Boakes, E. H., Carbone, C., Connolly, C., Cutts, M. 1. J.,Foster, J. K., Grenyer, R., Habib, M., Plaster, C. A., Price, S. A., Rigby, E. A., Rist, J.,Teacher, A., Bininda-Emonds, O. R. P., Gittleman, J. L., Mace, G. M. \& Purvis, A., 2009. 
PanTHERIA: A species-level database of life-history, ecology and geography of extant and recently extinct mammals. Ecology 90, 2648.

Kapur, V.V., Bajpai, S., 2015. Oldest South Asian tapiromorph (Perissodactyla, Mammalia) from the Cambay Shale Formation, western India, with comments on its phylogenetic position and biogeographic implications. The Palaeobotanist 64, 95-103.

Kay, R.F., Fleagle, J.G., Mitchell, T.R.T., Colbert, M., Bown, T., Powers, D.W., 2008. The anatomy of Dolichocebus gaimanensis, a stem platyrrhine monkey from Argentina. J. Hum. Evol. 54, 323-382.

Kear, B.P., Pledge, N.S., 2008. A new fossil kangaroo from the Oligocene-Miocene Etadunna Formation of Ngama Quarry, Lake Palankarinna, South Australia. Aust. J. Zool. 55, 331-339.

Kear, B.P., Cooke, B.N., Archer, M., Flannery, T.F., 2007 Implications of a new species of the Oligo-Miocene kangaroo (Marsupialia: Macropodoidea) Nambaroo, from the Riversleigh World Heritage Area, Queensland, Australia. J. Paleontol. 81, 1147-1167.

Kocsis, L., Gheerbrant, E., Mouflih, M., Cappetta, H., Yans, J., Amaghzaz, M., 2014. Comprehensive stable isotope investigation of marine biogenic apatite from the late Cretaceous-early Eocene phosphate series of Morocco. Palaeogeogr. Palaeoclimatol. Palaeoecol. 394, 74-88.

Korth, W.W., 1994. The Tertiary Record of Rodents in North America. Plenum Press, New York, NY.

Krause, D.W., Hoffman, S., Wible, J.R., Kirk, E.C., Schultz, J.A., von Koenigswald, W., Groenke, J.R., Rossie, J.B., O'Connor, P.M., Seiffert, E.R., Dumont, E.R., Holloway, W.L., Rogers, R.R., Rahantarisoa, L.J., Kemp,k A.D., Andriamialison, H., 2014. First cranial remains of a gondwanatherian mammal reveal remarkable mosaicism. Nature 
$515,512-517$.

Lambert, O., Louwye, S., 2006. Archaeoziphius microglenoideus, a new primitive beaked whale (Mammalia, Cetacea, Odontoceti) from the middle Miocene of Belgium. J. Vertebr. Paleontol. 26, 182-191.

Lambert, O., Bianucci, G., de Muizon, C., 2008. A new stem-sperm whale (Cetacea, Odontoceti, Physeteroidea) from the Latest Miocene of Peru. C. R. Palevol 7, 361-369.

Lartillot, N., Delsuc, F., 2012. Joint reconstruction of divergence times and life-history evolution in placental mammals using a phylogenetic covariance model. Evolution 66, 1773-1787.

Lazzari, V., Charles, c., Tafforeau, P., Vianey-Liaud, M., Aguilar, J.-P., Jaeger, J.-J., Michaux, J., Viriot, L., 2008. Mosaic convergence of rodent dentitions. PLoS One 3, 3607.

Lebatard, A.-E., Bourlès, Duringer, P., Jolivet, M., Braucher, R., Carcaillet, J., Schuster, M., Arnaud, N., Monié, P., Lihoreau, F., Likius,k A., Mackaye, H.T., Vignaud, P., Brunet, M., 2008. Cosmogenic nuclide dating of Sahelanthropus tchadensis and Australopithecus habrelghazali: Mio-Pliocene hominids from Chad. Proc. Natl. Acad. Sci. USA 105, 3226-3231.

Li, Q., Meng, J., 2010. Erlianomys combinatus, a primitive myodont rodent from the Eocene Arshanto Formation, Nuhetingboerhe, Nei Mongol, China. Vertebr. Palasiatica 48, 133-144.

Li, Q., Ni, X., 2016. An early Oligocene fossil demonstrates treeshrews are slowly evolving "living fossils". Sci. Reports 6, 18627. 
Lim, B.K., 2009. Review of the origins and biogeography of bats in South America. Chiroptera Neotropical 15, 391-410.

Luo, Z.-X., 2007. Transformation and diversification in early mammal evolution. Nature 450, 1011-1019

Luo, Z.-X., Cifelli, R.L., Kielan-Jaworowska, Z., 2001 Dual origin of tribosphenic mammals. Nature 409, 53-57.

Luo, Z.X., Gatesy, S.M., Jenkins, F.A., Amaral, W.W., Shubin, N.H., 2015. Mandibular and dental characteristics of Late Triassic mammaliaform Haramiyavia and their ramifications for basal mammal evolution. Proc. Natl. Acad. Sci. USA 112, E7101E7109.

MacPhee, R.D.E., Iturralde-Vinent, M.A., Gaffney, E.S., 2003. Domo de Zaza, an early Miocene vertebrate locality in South-Central Cuba, with notes on the tectonic evolution of Puerto Rico and the Mona Passage. Am. Mus. Novitat. 3394, 1-42.

Madsen, O., Scally, M., Douady, C.J., Kao, D.J., DeBry, R.W., Adkins, R., Amrine, H.M., Stanhope, M.J., de Jong, W.W., Springer, M.S., 2001. Parallel adaptive radiations in two major clades of placental mammals. Nature 409, 610-614.

Magelhães, J.P., Costa, J., 2009. A database of vertebrate longebity rcords and their relation to other life-history traits. J. Evol. Biol. 22, 1770-1774.

Marshall, C.R., 1990. Confidence intervals on stratigraphic ranges with nonrandom distributions of fossil horizons. Paleobiology 23, 165-173.

McKenna, M. C., Bell, S. K., 1997. Classification of Mammals Above the Species Level. Columbia University Press, New York. 
Meredith, R.W., Janecka, J.E., Gatesy, J., Ryder, O.A., Fisher, C.A., Teeling, E.C., Goodbla, A., Eizirik, E., Simão, T.L.L., Stadler, T., Rabosky, D.L., Honeycutt, R.L., Flynn, J.J., Ingram, C.M., Steiner, C., Williams, T.L., Robinson, T.J., Burk-Herrick, A., Westerman, M., Ayoub, N.A., Springer, M.S., Murphy, W.J., 2011a. Impacts of the Cretaceous Terrestrial Revolution and KPg extinction on mammal diversification. Science 334, 521-524.

Meredith, R.W., Westerman, M., Case, J.A., Springer, M.S., 2008. A phylogeny and timescale for marsupial evolution based on sequences for five nuclear genes J. Mamm. Evol. 15, 1-36.

Morgan, G.S., Czaplewski, N.J., 2003. A new bat (Chiroptera: Natalidae) from the early Miocene of Florida, with comments on natalid phylogeny. J. Mammal. 84, 729-752.

Murphy, W.J., Eizirik, E., Johnson, W.E., Zhang, Y.P., Ryder, O.A., O’Brien, S.J., 2001a. Molecular phylogenetics and the origins of placental mammals. Nature 409, 614618.

Murphy, W.J., Eizirik, E., O’Brien, S.J., Madsen, O., Scally, M., Douady, C.J., Teeling, E., Ryder, O.A., Stanhope, M.J., de Jong, W.W., Springer, M.S., 2001b. Resolution of the early placental mammal radiation using Bayesian phylogenetics. Science 294, 2348-2351.

Ni, X., Qiu, Z., 2012. Tupaiine tree shrews (Scandentia, Mammalia) from the Yuanmou Lufengpithecus locality of Yunnan, China. Swiss J. Palaeontol. 131, 51-60.

Nishihara, H., Maruyama, S. and Okada, N., 2009. Retroposon analysis and recent geological data suggest near-simultaneous divergence of the three superorders of mammals. Proc. Natl. Acad. Sci. USA 106, 5235-5240.

O’Leary, M.A., Bloch, J.I., Flynn, J.J., Gaudin, T.J., Giallombardo, A., Giannini, N.P., Goldberg, S.L., Kraatz, B.P., Luo, Z.-X., Meng, J., Ni, X., Novacek, M.J., Perini, F.A., 
Randall, Z.S., Rougier, G.W., Sargis, E.J., Silcox, M.T., Simmons, N.B., Spaulding, M., Velazco, P.M., Weksler, M., Wible, J.R., Cirranello, A.L., 2013. The placental mammal ancestor and the post-K-Pg radiation of placentals. Science 339, 662-667.

Phillips, M., 2015. Four mammal fossil calibrations: balancing competing palaeontological and molecular considerations Palaeontologia Electronica 1815FC, 1-16.

Phillips, M., 2016. Geomolecular dating and the origin of placental mammals. Syst. Biol. $65,546-557$.

Pickford, M., Hlusko, L.J., 2007. Late Miocene procaviid hyracoids (Hyracoidea: Dendrohyrax) from Lemudong'o, Kenya. Kirtlandia 56, 106-111.

Ravel, A., Marivaux, L., Tabuce, R., Ali, M.B.J., Essid, E.M., Vianey-Liaud, M., 2012. A new large philisid (Mammalia, Chiroptera, Vespertilionoidea) from the late early Eocene of Chambi, Tunisia. Palaeontology 55, 1035-1041.

Rodrigues, H.G., Charles, C., Marivaux, L., Vianey-Liaud, M., Viriot, L., 2011. Evolutionary and developmental dynamics of the dentition in Muroidea and Dipodoidea (Rodentia, Mammalia). Evol. Develop. 13, 361-369.

Romiguier, J., Ranwez, V., Douzery, E.J.P., Galtier, N., 2013. Genomic evidence for large, long-lived ancestors to placental mammals. Mol. Biol. Evol. 30, 5-13.

Rose, K.D., DeLeon, V.B., Missiaen, P., Rana, R.S., Sahni, A., Singh, L., Smith, T., 2008. Early Eocene lagomorph (Mammalia) from Western India and the early diversification of Lagomorpha. Proc. R. Soc. B 275, 1203-1208.

Rowe, T., Rich, T.H., Vickers-Rich, P., Springer, M., Woodburne, M.O., 2008. The oldest platypus and its bearing on divergence timing of the platypus and echidna clades. Proc. Natl. Acad. Sci. USA 105, 1238-1242. 
Sansom, R.S., Wills, M.A., 2013. Fossilization causes organisms to appear erroneously primitive by distorting evolutionary trees. Sci. Reports 3, 2545.

Sato, J.J., Ohdachi, S.D., Echenique-Diaz, L.M., Borroto-Páez, R., Beguè-Quiala, G., Delgado-Labañino, J.L., Gámez-Diez, J., Alvarez-Lemus, J., Nguyen, S.T., Yamaguchi, N., Kita, M., 2016. Molecular phylogenetic analysis of nuclear genes suggests a Cenozoic over-water dispersal origin for the Cuban solenodon. Sci. Rep. 6, 31173.

Schmitt, A., Gheerbrant, E., 2016. The ear region of earliest known elephant relatives: new light on the ancestral morphotype of proboscideans and afrotherians. J. Anat. 228, 137-152.

Seiffert, E.R., Simons, E.L., Attia, Y., 2003. Fossil evidence for an ancient divergence of lorises and galagos. Nature 422, 421-424.

Seiffert, E.R., Simons, E.L., Ryan, T.M., Bown, T.M., Attia, Y., 2007. New remains of Eocene and Oligocene Afrosoricida (Afrotheria) from Egypt, with implications for the origin(s) of afrosoricid zalambdodonty. J. Vertebr. Paleontol. 27, 963-972.

Setoguchi, T., Rosenberger, A.L., 1987. A fossil owl monkey from La Venta, Colombia. Nature 326, 692-694.

Slater, G. J., 2013. Phylogenetic evidence for a shift in the mode of mammalian body size evolution at the Cretaceous-Palaeogene boundary. Methods Ecol. Evol. 4, 734-744.

Solounias, N., Barry, J.C., Bernor, R.L., Lindsay, E.H., Raza, S.M., 1995. The oldest bovid from the Siwaliks, Pakistan. J. Vertebr. Paleontol. 15, 806-814.

Spaulding, M., Flynn, J.J., 2009. Anatomy of the postcranial skeleton of "Miacis" uintensis (Mammalia: Carnivoramorpha). J. Vertebr. Paleontol. 29, 1212-1223. 
Springer, M.S., 1990. The effect of random range truncations on patterns of evolution in the fossil record. Paleobiology 16, 512-520.

Springer, M., Lilje, A., 1988. Gap analysis and biostratigraphy: the expected sequence of biostratigraphic events. J. Geol. 96, 228-236.

Springer, M.S., Burk-Herrick, A., Meredith, R., Eizirik, E., Teeling, E., O’Brien, S.J., Murphy, W.J., 2007a. The adequacy of morphology for reconstructing the early history of placental mammals. Syst. Biol. 56, 673-684.

Springer, M.S., Meredith, R.W., Eizirik, E., Teeling, E., Murphy, W.J., 2008. Morphology and placental mammal phylogeny. Syst. Biol. 57, 499-503.

Springer, M.S., Meredith, R.W., Gatesy, J., Emerling, C.A., Park, J., Rabosky, D.L., Stadler, T., Steiner, C., Ryder, O.A., Janečka, J.E., Fisher, C.A., Murphy, W.J. 2012. Macroevolutionary dynamics and historical biogeography of primate diversification inferred from a species supermatrix. PLoS ONE 7, e49521.

Springer, M.S., Meredith, R.W., Teeling, E.C., Murphy, W.J., 2013. Technical comment on "The placental mammal ancestor and the Post-K-Pg radiation of placentals". Science 341, 613-b.

Springer, M.S., Murphy, W.J., Eizirik, E., Madsen, O., Scally, M., Douady, C.J., Teeling, E.C., Stanhope, M.J., de Jong, W.W., O'Brien, S.J., 2007b. A molecular classification for the living orders of placental mammals and the phylogenetic placement of primates. In: Ravosa, M.J., Dagosto, M. (Eds.), Primate Origins: Adaptations and Evolution. Springer, New York, pp. 1-28. 
Springer, M.S., Murphy, W.J., Eizirik, E., O’Brien, S.J., 2003. Placental mammal diversification and the Cretaceous-Tertiary boundary. Proc. Natl. Acad. Sci. USA 100, 1056-1061.

Springer, M.S., Murphy, W.J., Eizirik, E., O'Brien, S.J., 2005. Evidence for major placental clades. In: Rose, K.D., Archibald, J.D. (Eds.), The Rise of Placental Mammals: Origins and Relationships of the Major Extant C. Johns Hopkins University Press, Baltimore, pp. 37-49.

Springer, M.S., Signore, A.V., Paijmans, J.L.A., Vélez-Juarbe, J., Domning, D.P., Bauer, C.E., He, K., Crerar, L., Campos, P.F., Murphy, W.J., Meredith, R.W., Gatesy, J., Willerslev, E., MacPhee, R.D.E., Hofreiter, M., Campbell, K.L., 2015. Interordinal gene capture, the phylogenetic position of Steller's sea cow based on molecular and morphological data, and the macroevolutionary history of Sirenia. Mol. Phylogenet. Evol. 91, 178-193.

Springer, M.S., Stanhope, M.J., Madsen, O., de Jong, W.W., 2004. Molecules consolidate the placental mammal tree. Trends Ecol. Evol., 19, 430-438.

Storch, G., Sigé, B., Habersetzer, J., 2002. Tachypteron franzeni n. gen., n. sp., earliest emballonurid bat from the middle Eocene of Messel (Mammalia, Chiroptera). Paläontol. Zeit. 76, 189-199.

Strauss, D., Sadler, P.M., 1989. Classical confidence intervals and Bayesian probability estimates for the ends of local taxon ranges. Math. Geol. 21, 411-426.

Swofford, D.L., 2002. PAUP*. Phylogenetic Analysis Using Parsimony (*and Other Methods). Sinauer Associates, Sunderland, Massachusetts.

Tabuce, R., Asher, R.J., Lehmann, T., 2008. Afrotherian mammals: a review of current data. Mammalia 72, 2-14. 
Tarver, J.E., dos Reis, M., Mirarab, S., Moran, R.J., Parker, S., O’Reilly, J.E., King, B.L., O’Connell, M.J., Asher, R.J., Warnow, T., Peterson, K.J., Donoghue, P.C.J., Pisani, D., 2016. The interrelationships of placental mammals and the limits of phylogenetic inference. Genome Biol Evol. 8, 330-344.

Teeling, E.C., Springer, M.S., Madsen, O., Bates, P., O’Brien, S.J., Murphy, W.J., 2005. A molecular phylogeny for bats illuminates biogeography and the fossil record. Science $307,580-584$.

Theodor, J.M., 2004. Molecular clock divergence estimates and the fossil record of Cetartiodactyla. J. Paleontol. 78, 39-44.

Tong, Y., 1988. Fossil tree shrews from the Eocene Hetaoyuan formation of Xichuan, Henan. Vertebrata Palasiatica 26, 214-220.

Turnbull, W.D., Lundelius, E.L. Jr, Archer, M., 2003. Dasyurids, perameloids, phalangeroids, and vombatoids from the early Pliocene Hamilton Fauna, Victoria, Australia. Bull. Am. Mus. Nat. Hist. 279, 513-540.

Uhen, M.D., 2010. The origin(s) of whales. Annu. Rev. Earth Planet. Sci. 38, 189-219.

Uhen, M.D., Fordyce, R.E., Barnes, L.G., 2008. Odontoceti. In: Janis, C.M., Gunnell, G.F., Uhen, M.D. (Eds.), Evolution of Tertiary Mammals of North America, volume 2. Cambridge University Press, New York, NY, pp. 566-606.

Varela, S., Gonzalez-Hernandez, J., Sgarbi, L.F., 2014. paleobioDB: an R-package for downloading, visualizing and processing data from the Paleobiology Database. $R$ package version 0.1. https://github.com/ropensci/paleobioDB.

Vélez-Juarbe, J., Domning, D.P., 2014. Fossil Sirenia of the West Atlantic and Caribbean 
region. IX. Metaxytherium albifontanum, sp. nov. J. Vertebr. Paleontol. 34, 444-464.

Vignaud, P., Duringer, P., Mackaye, H.T., Likius, A., Blondel, C., Boisserie, J.-R., de Bonis, L., Eisenmann, V., Etienne, M.-E., Geraads, D., Guy, F., Lehmann, T., Lihoreau, F., Lopez-Martinez, N., Mourer-Chauviré, Otero, O., Rage, J.-C., Schuster, M., Viriot, L., Zazzo, A., Brunet, M., 2002. Geology and palaeontology of the Upper Miocene TorosMenalla hominid locality, Chad. Nature 418, 152-155.

Vucetich, M.G., Verzi, D.H., Hartenberger, J.-L., 1999. Review and analysis of the radiation of the South American. C. R. Acad. Sci. Paris Earth Planet. Sci. 329, 763-769.

Wang, X.-M., Tedford, R.H., 1996. Canidae. In: Prothero, D.R., Emry, R.J. (Eds.), The Terrestrial Eocene-Oligocene Transition in North America. Cambridge University Press, New York, NY, pp. 433-452.

Wang, X., McKenna, M.C., Dashzeveg, D., 2005. Amphicticeps and Amphicynodon (Arctoidea, Carnivora) from Hsanda Gol Formation, Central Mongolia and phylogeny of basal arctoids with comments on zoogeography. Am. Mus. Novitat. 3483, 1-57.

Wesley-Hunt, G.D., Flynn, J.J., 2005. Phylogeny of the Carnivora: basal relationships among the carnivoramorphans, and assessment of the position of 'Miacoidea' relative to Carnivora. J. Syst. Palaeontol. 31, 1-28.

Wible, J.R., Rougier, G.W., Novacek, M.J., Asher, R.J., 2009. The eutherian mammal Maelestes gobiensis from the Late Cretaceous of Mongolia and the phylogeny of Cretaceous Eutheria. Bull. Am. Mus. Nat. Hist. 327, 1-123.

Wildman, D.E., Uddin, M., Opazo, J.C., Liu, G., Lefort, V., Guindon, S., Gascuel, O., Grossman, L.I.., Romero, R., Goodman, M., 2007. Genomics, biogeography, and the diversification of placental mammals. Proc. Natl. Acad. Sci. USA 104, 14395-14400. 
Williams, B.A., Kay, R.F., Kirk, E.C., 2010. New perspectives on anthropoid origins. Proc. Natl. Acad. Sci. USA 107, 4797-4804.

Woodburne, M.O., Goin, F.J., Bond, M., Carlini, A.A., Gelfo, J.N., López, G.M., Iglesias, A., Zimicz, A.M., 2014. Paleogene land mammal faunas of South America; a response to global climatic changes and indigenous floral diversity. J. Mamm. Evol. 21, $1-73$.

Woodburne, M.O., Gunnell, G.F., Stucky, R.K., 2009. Climate directly influences Eocene mammal faunal dynamics in North America. Proc. Natl. Acad. Sci. USA 106, 13399-13403.

Woodburne, M.O., MacFadden, B.J., Case, J.A., Springer, M.S., Pledge, N.S., Power, J.D., Woodburne, J.M., Springer, K.S., 1993. Land mammal biostratigraphy and magnetostratigraphy of the Etadunna Formation (late Oligocene) of South Australia. J. Vertebr. Paleontol. 13, 483-515.

Woodburne, M.O., Rich, T.H., Springer, M.S., 2003. The evolution of tribospheny and the antiquity of mammalian clades. Mol. Phylogenet. Evol. 28, 360-385.

Wroe, S., 1999. The geologically oldest dasyurid, from the Miocene of Riversleigh, north-west Queensland. Palaeontology 42, 501-527.

Yang, Z., 2007. PAML 4: phylogenetic analysis by maximum likelihood. Mol. Biol. Evol. 24, 1586-1591.

Zárate, M.A., Schultz, P.H., Blasi, A., Heil, C., King, J., Hames, W., 2007. Geology and geochronology of type Chasicoan (late Miocene) mammal-bearing deposits of Buenos Aires (Argentina). J. So. Am. Earth Sci. 23, 81-90. 
Zhou, C.-F., Wu, S., Martin, T., Luo, Z.-X., 2013. A Jurassic mammaliaform and the earliest mammalian evolutionary adaptations. Nature 500, 163-167.

\section{Legends for Figures}

Fig. 1. Depiction of ghost (A) versus zombie (B) lineages. A. True tree and divergence time for extant sister taxa 1 and 2. Individual fossil occurrences are plotted by age and define the observed stratigraphic ranges (green rectangles) of taxa 1 and 2 . The older range of Taxon 1 requires a ghost lineage for Taxon 2 (pink rectangle). If the true divergence time for taxa 1 and 2 is older than the oldest fossil for either lineage, then additional ghost lineages (red rectangles) are required for Taxon 1 and Taxon 2 . B. The estimated divergence time between taxon 1 and taxon 2 is younger than the minimum age for this divergence as defined by the fossil record. The difference between the minimum age required by the oldest fossil and the estimated age on a timetree is a zombie lineage (blue rectangle).

Fig. 2. Zombie lineages in Phillips' (2016) preferred tree, which is based on 27 calibrations from dos Reis et al. (2012) and new maximum bounds for Chiroptera, Primates, and Rodentia. Branches with zombie lineages, which have parent nodes that are younger than minimum ages implied by fossils, are highlighted with red branches. Paintings by Carl Buell.

Fig. 3. Timetree for 117 mammalian taxa from Meredith et al. (2011) after excluding 47 taxa with body size $>10 \mathrm{~kg}$ and/or lifespan > 40 years. The RAxML phylogram for timetree analyses was obtained by deleting 47 taxa from Meredith et al.'s (2011) 169taxon, DNA tree that exceed threshold criteria for large body size and long lifespan. Bootstrap support percentages and Bayesian posterior probabilities for the original tree are provided in Meredith et al. (2011). The timetree is based on momctree with autocorrelated rates and hard-bounded constraints. Calibrated nodes (Table 1) within Mammalia are shown with filled black circles. Interordinal divergences within Placentalia are denoted with open red circles and are all in the Cretaceous (see Table 3 
for $95 \%$ credibility intervals). Interordinal divergence times based on other combinations of autocorrelated versus independent rates and hard-bounded versus soft-bounded constraints are provided in Table 3. The KPg boundary is denoted with a dashed blue line. Non-mammalian outgroups are not shown. Paintings by Carl Buell.

Fig. 4. Illustration of long-branch misplacement resulting from diachronous terminals, which is intensified by correlated homoplasy. A. The true evolutionary tree showing relationships among taxa $\mathrm{W}, \mathrm{X}, \mathrm{Y}, \mathrm{Z}$. Taxa $\mathrm{X}$ and $\mathrm{W}$ represent extant species and taxa $\mathrm{Y}$ and $\mathrm{Z}$ represent fossil species. Taxa $\mathrm{X}$ and $\mathrm{Y}$ are united by one shared derived character without homoplasy (character 9). Taxa $\mathrm{W}$ and $\mathrm{Z}$ are united by two shared derived characters without homoplasy (characters 10 and 11). Taxa X and $\mathrm{W}$ share eight homoplastic characters, four of which (1-4) result from random homoplasy on long branches and four of which (5-8) are the result of parallel evolutionary trends that create opportunities for correlated homoplasy. The minimum fossil constraint for the split between taxa $\mathrm{X}$ and $\mathrm{W}$ is based on taxon $\mathrm{Y}$. B. The reconstructed tree based on parsimony deltran optimization. The presence of homoplasy results in a reconstructed tree that fails to recover true evolutionary relationships. Instead, random homoplasy (characters 1-4) on the long branches $\mathrm{X}$ and $\mathrm{W}$ attracts these taxa together. Long branch misplacement is further exacerbated when there are parallel evolutionary constraints (characters 5-8). In the reconstructed tree, the minimum age for the split between $X$ and $\mathrm{W}$ is incorrect and provides an underestimate of the true minimum age because $\mathrm{Y}$ and $\mathrm{Z}$ are outside of the crown clade.

Fig. 5. Plots that indicate the number of new lineages in each geological stage from the Cenomanian through the Lutetian. A. New fossil eutherian taxa as recorded by the Paleobiology Database. B. New lineages based on molecular timetrees. Arrows indicate rate changes relative to the previous geological stage: small arrows $=50-99.9 \%$; medium arrows $=100-999.9 \%$; large arrows $\geq 1000 \%$. Infinity signs show instances where the previous stage had no new lineages, and $-100 \%$ indicates zero new lineages in the current stage. dR27b = Phillips' (2016) timetree (169 taxa) based on 27 calibrations from dos Reis (2012) with modified maximum constraints for Chiroptera, Primates, and Rodentia; 
Mer82c = Phillips' (2016) reanalysis of Meredith et al.'s (2011) DNA supermatrix (169 taxa) with 82 calibrations (Mer82c); and Emer15 = Emerling et al.'s (2015) timetree (388 species) with calibrations at 77 nodes; Coniacia $=$ Coniacian; Santon $=$ Santonian; Selan $=$ Selandian; Thanet $=$ Thanetian .

\section{Glossary}

Ghost lineage: a lineage that is inferred to exist based but lacks a fossil record.

Zombie lineage: a lineage that has a fossil record that is older than a molecular divergence time estimate. 
A

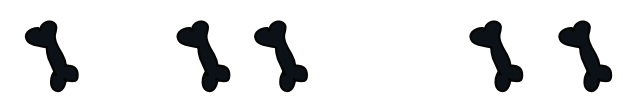

Taxon 1

Taxon 2

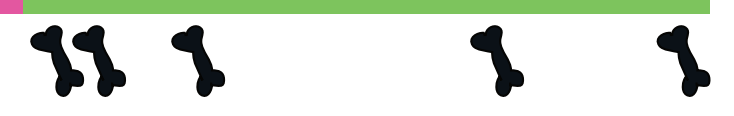

B

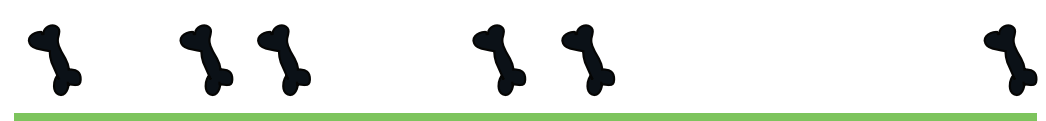

Taxon 1
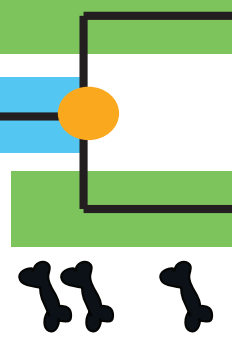

Time

$=$ true divergence time between taxon 1 and 2

$=$ estimated divergence time between taxon 1 and taxon 2

$=$ fossil occurrence

= observed taxon range

$=$ ghost lineage implied by fossil record of sister lineage

= ghost lineage resulting from incomplete fossil record in both lineages

$=$ zombie lineage resulting from crown fossil(s) that are older than timetree estimate 


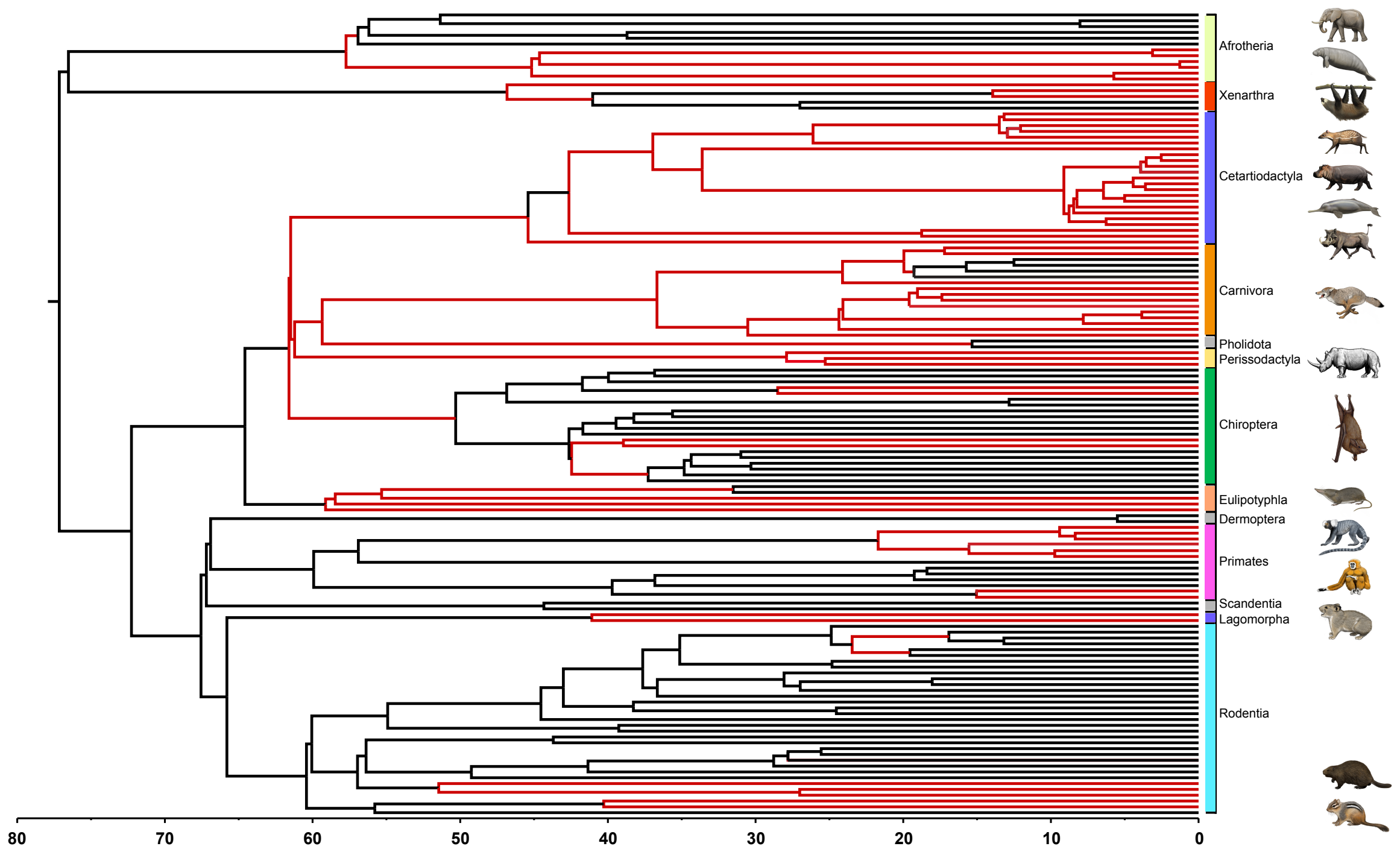

= branches with parent node on Phillips' (2016) timetree that is younger than minimum fossil age (= zombie lineages)

= branches with parent node on Phillips' (2016) timetree that is older than minimum fossil age 
Figure 3

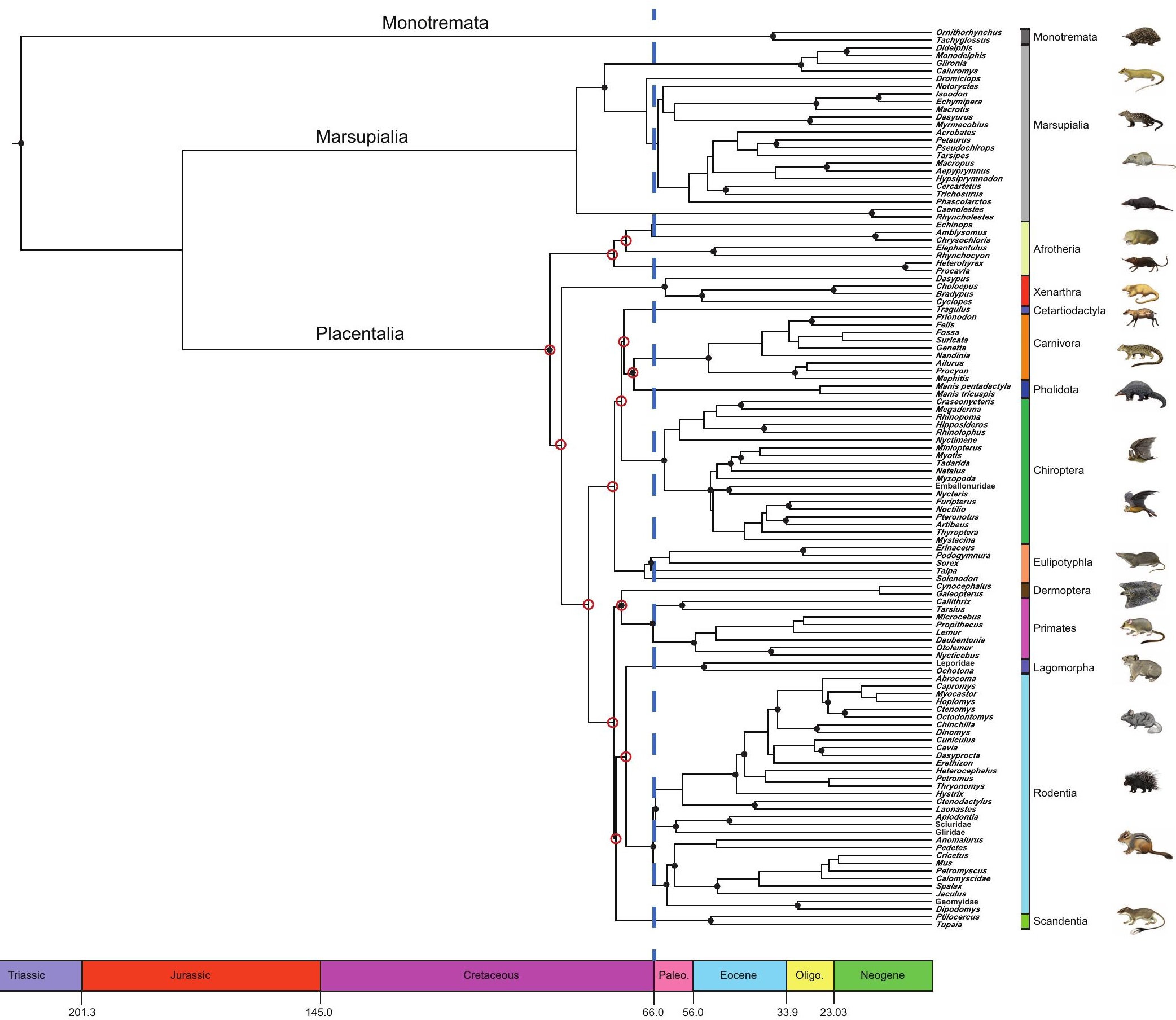


- Random homoplasy

Shared derived without homoplasy

- Additional homoplasy resulting from parallel evolutionary trends

\section{A. TRUE TREE}

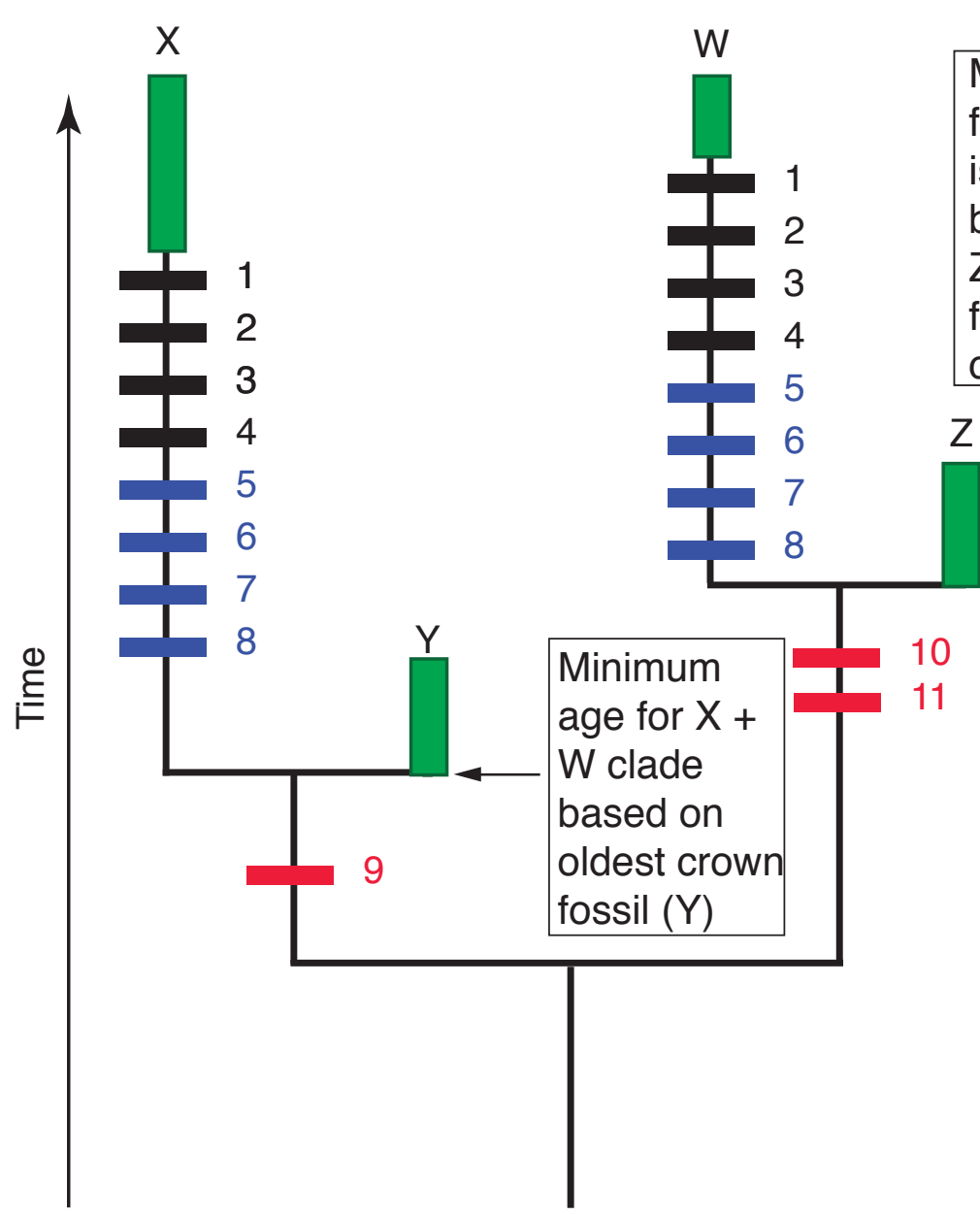

B. RECONSTRUCTED TREE

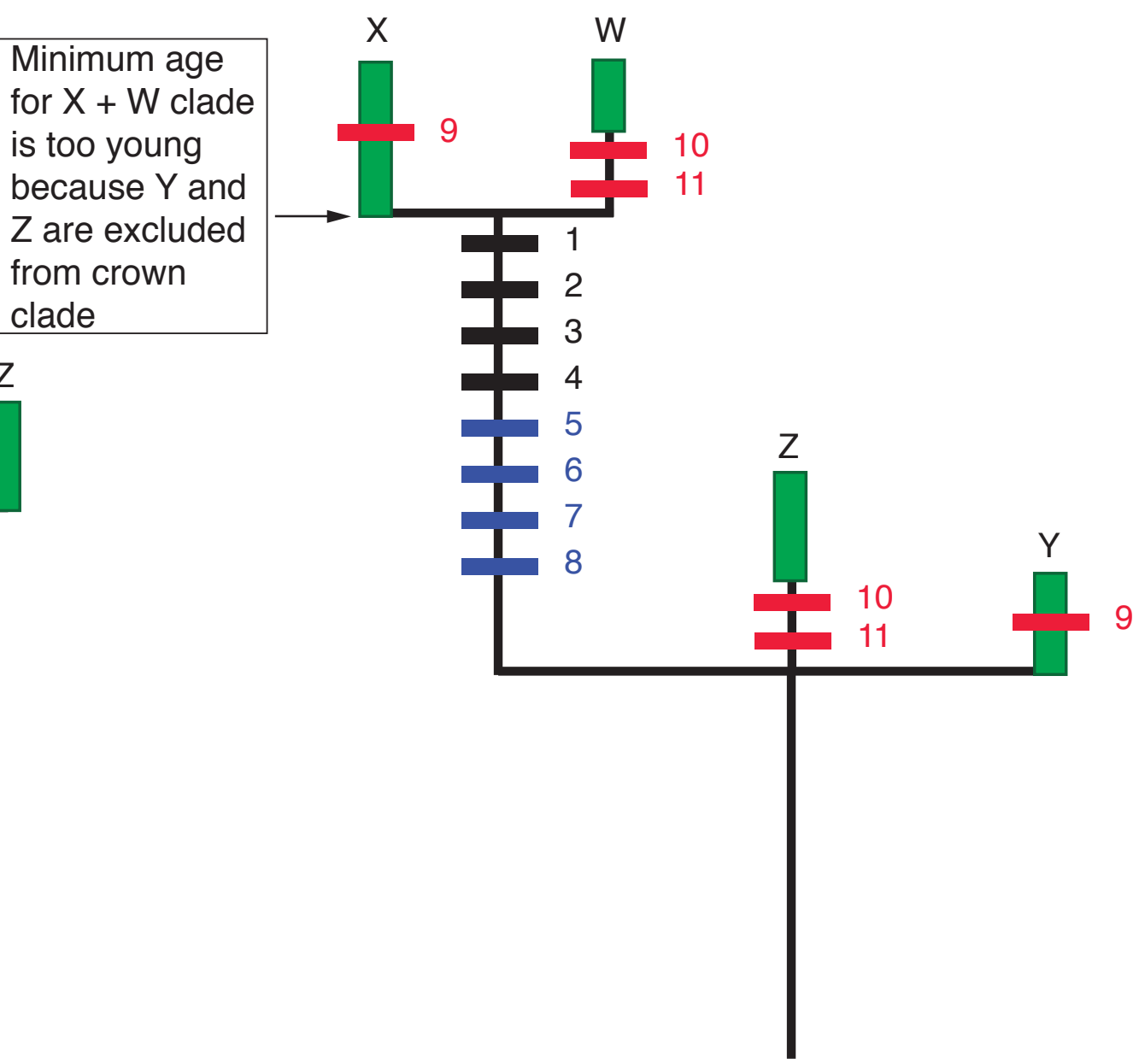


(A) Number of New Eutherian Fossil Taxa by Stage

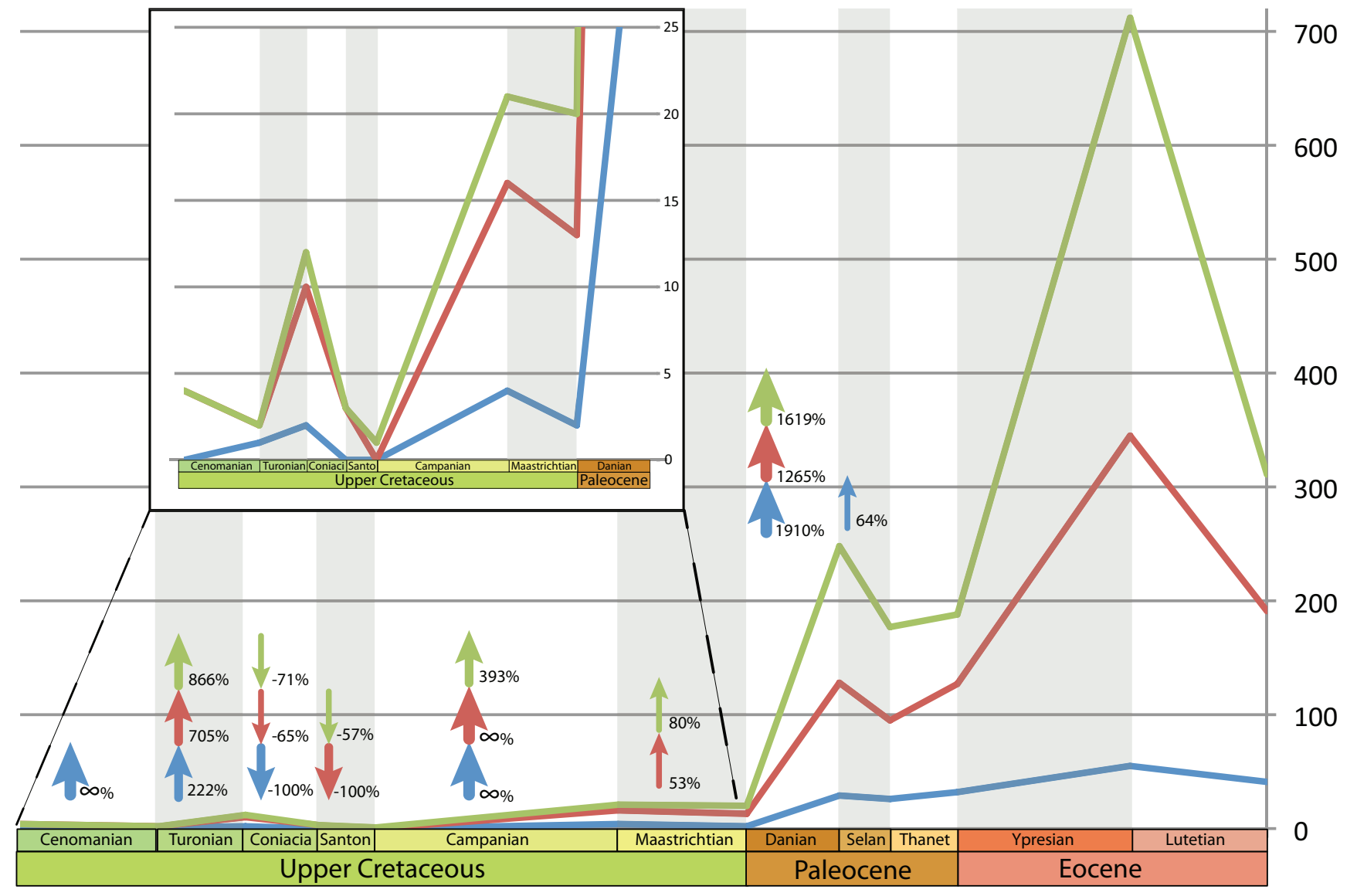

(B) Number of New Lineages by Stage

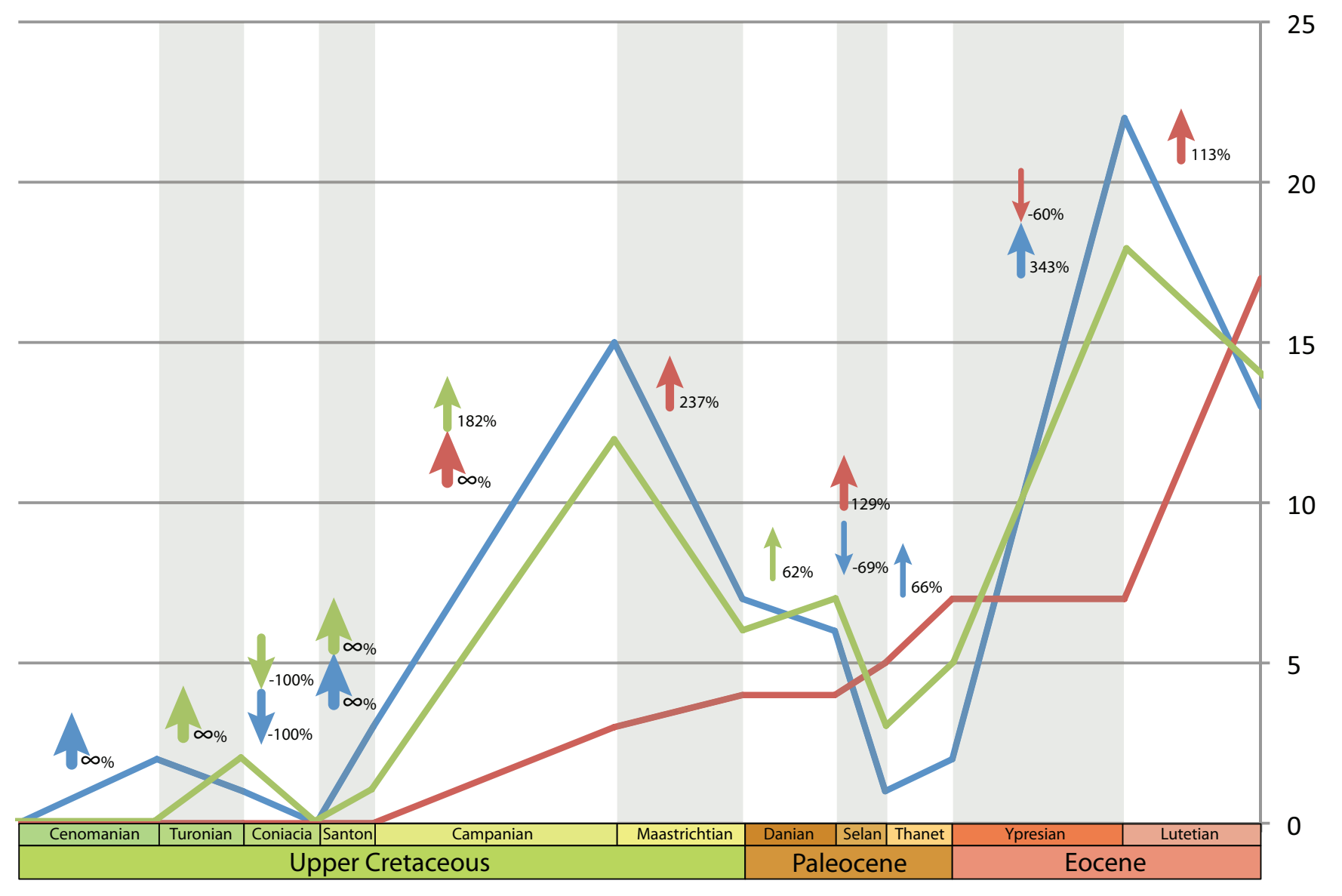


Table 1. Calibrations used in molecular dating analyses.

\begin{tabular}{|c|c|c|c|c|}
\hline Clade & $\begin{array}{l}\text { Oldest crown } \\
\text { fossil }\end{array}$ & $\begin{array}{l}\text { Minimum } \\
\text { age }\end{array}$ & Maximum age & $\begin{array}{l}\text { References for oldest fossil(s) and discussion of } \\
\text { calibration }\end{array}$ \\
\hline $\begin{array}{l}\text { 1. Actinopterygii + } \\
\text { Sarcopterygii }\end{array}$ & Guiyu oneiros & 420.7 & 444.9 & Benton et al. (2015) \\
\hline 2. Tetrapoda & Lethiscus stocki & 337 & 351 & Benton et al. (2015) \\
\hline 3. Amniota & Hylonomus lyelli & 318 & 332.9 & Benton et al. (2015) \\
\hline 4. Sauropsida & $\begin{array}{l}\text { Protorosaurus } \\
\text { speneri }\end{array}$ & 255.9 & 295.5 & Benton et al. (2015) \\
\hline 5. Neognathae & Vegavis iaai & 66.0 & 86.8 & Benton et al. (2015) \\
\hline 6. Mammalia & $\begin{array}{l}\text { Ambondro } \\
\text { mahabo }\end{array}$ & 164.9 & 227 & $\begin{array}{l}\text { Luo et al. (2001, 2015); Woodburne et al. (2003); } \\
\text { Bi et al. (2014); Krause et al. (2014); Benton et al. } \\
\text { (2015); Emerling et al. (2015) }\end{array}$ \\
\hline 7. Monotremata & $\begin{array}{l}\text { Obdurodon } \\
\text { insignis }\end{array}$ & 25.0 & 121 & $\begin{array}{l}\text { Rowe et al. (2008); Meredith et al. (2011); } \\
\text { Emerling et al. (2015) }\end{array}$ \\
\hline 8. Caenolestidae & None & 0 & 15.97 & Goin et al. (2007, 2009); Emerling et al. (2015) \\
\hline $\begin{array}{l}\text { 9. Didelphimorphia + } \\
\text { Australidelphia }\end{array}$ & Peradectes & 65.18 & 83.8 & Horovitz et al. (2009); Emerling et al. (2015) \\
\hline 10. Didelphidae & $\begin{array}{l}\text { Micoureus } \\
\text { laventicus }\end{array}$ & 11.608 & 20.44 & Goin (1997); Emerling et al. (2015) \\
\hline 11. Didelphimorphia & $\begin{array}{l}\text { Micoureus } \\
\text { laventicus }\end{array}$ & 11.608 & 66.0 & Emerling et al. (2015) \\
\hline 12. Dasyuromorphia & Barinya wangala & 15.97 & 54.65 & Wroe (1999); Emerling et al. (2015) \\
\hline 13. Peramelidae & cf. Peroryctes & 4.36 & 23.8 & Turnbull et al. (2003); Emerling et al. (2015) \\
\hline 14. Peramelemorphia & cf. Peroryctes & 4.36 & 54.65 & $\begin{array}{l}\text { Godthelp et al. (1992); Turnbull et al. (2003); } \\
\text { Emerling et al. (2015) }\end{array}$ \\
\hline $\begin{array}{l}\text { 15. Burramyidae }+ \\
\text { Phalangeridae }\end{array}$ & $\begin{array}{l}\text { Eocuscus } \\
\text { sarastamppi }\end{array}$ & 25.0 & 54.65 & Case et al. (2009); Emerling et al. (2015) \\
\hline 16. Petauridae + & Paljara sp. A & 25.5 & 54.65 & Woodburne et al. (1993); Emerling et al. (2015) \\
\hline
\end{tabular}




\begin{tabular}{|c|c|c|c|c|}
\hline Pseudocheiridae & & & & \\
\hline $\begin{array}{l}\text { 17. Macropodidae }+ \\
\text { Potoroidae }\end{array}$ & $\begin{array}{l}\text { Bulungamaya } \\
\text { delicata }\end{array}$ & $24.7^{\mathrm{A}}$ & 54.65 & $\begin{array}{l}\text { Woodburne et al. (1993); Kear et al. (2007); Kear } \\
\text { and Pledge (2008); Meredith et al. (2011); } \\
\text { Emerling et al. (2015) }\end{array}$ \\
\hline 18. Placentalia & Purgatorius & 65.2 & 131.5 & Benton et al. (2009); Chester et al. (2015) \\
\hline 19. Chrysochloridae & $\begin{array}{l}\text { Amblysomus } \\
\text { julianae }\end{array}$ & 1.7 & 33.9 & $\begin{array}{l}\text { Avery (2001); Seiffert et al. (2007); Emerling et } \\
\text { al. (2015) }\end{array}$ \\
\hline 20. Macroscelidea & Myohyrax & 15.97 & 56.0 & $\begin{array}{l}\text { McKenna and Bell (1997); Tabuce et al. (2008); } \\
\text { Emerling et al. (2015) }\end{array}$ \\
\hline 21. Hyracoidea & Dendrohyrax & 6.08 & 11.62 & $\begin{array}{l}\text { Pickford and Hlusko (2007); Emerling et al. } \\
\text { (2015); Springer et al. (2015) }\end{array}$ \\
\hline 22. Xenarthra & Riostegotherium & 47.8 & 66.0 & $\begin{array}{l}\text { Bergqvist et al. (2004); Woodburne et al. (2014); } \\
\text { Emerling et al. (2015) }\end{array}$ \\
\hline 23. Pilosa & $\begin{array}{l}\text { Pseudoglyptodon } \\
\text { chilensis }\end{array}$ & 31.5 & 66.0 & Emerling et al. (2015) \\
\hline 24. Tardigrada & $\begin{array}{l}\text { Megalonychidae } \\
\text { fossils }\end{array}$ & 15.97 & 41.3 & Emerling et al. (2015) \\
\hline $\begin{array}{l}\text { 25. Prionodontidae }+ \\
\text { Felidae }\end{array}$ & $\begin{array}{l}\text { Proailurus } \\
\text { lemanensis, } \\
\text { Stenogale julieni }\end{array}$ & 28.1 & 41.3 & $\begin{array}{l}\text { Hunt (1998); Wesley-Hunt and Flynn (2005); } \\
\text { Holliday (2007); Emerling et al. (2015) }\end{array}$ \\
\hline 26. Carnivora & $\begin{array}{l}\text { Hesperocyon } \\
\text { gregarious }\end{array}$ & 38.0 & 66.0 & $\begin{array}{l}\text { Wesley-Hunt and Flynn (2005); Benton et al. } \\
\text { (2009); Spaulding and Flynn (2009); Emerling et } \\
\text { al. (2015) }\end{array}$ \\
\hline 27. Musteloidea & Promartes & 24.8 & 38.0 & Finarelli (2008); Paleobiology Database \\
\hline 28. Ostentoria & Ravenictis & 64.0 & 83.8 & Fox et al. (2010) \\
\hline $\begin{array}{l}\text { 29. Craseonycteridae } \\
+ \text { Megadermatidae }\end{array}$ & Saharaderma & 33.9 & 47.8 & Eiting and Gunnell (2009); Emerling et al. (2015) \\
\hline $\begin{array}{l}\text { 30. Hipposideridae }+ \\
\text { Rhinolophidae }\end{array}$ & Hipposideros & 38.0 & 56.0 & $\begin{array}{l}\text { Gunnell and Simmons (2005); Eiting and Gunnell } \\
\text { (2009); Emerling et al. (2015) }\end{array}$ \\
\hline 31. Chiroptera & Tachypteron & 47.8 & $66.0^{\mathrm{B}}$ & Storch et al. (2002); Ravel et al. (2012); Emerling \\
\hline
\end{tabular}




\begin{tabular}{|c|c|c|c|c|}
\hline & $\begin{array}{l}\text { franzeni, } \\
\text { Witwatia sigei, } \\
\text { Dizzya exsultans }\end{array}$ & & & et al. (2015); Phllips (2016) \\
\hline $\begin{array}{l}\text { 32. Emballonuridae + } \\
\text { Nycteridae }\end{array}$ & $\begin{array}{l}\text { Tachypteron } \\
\text { franzeni }^{\mathrm{C}}\end{array}$ & 47.8 & 59.2 & $\begin{array}{l}\text { Storch et al. (2002); Emerling et al. (2015); Phllips } \\
\text { (2016) }\end{array}$ \\
\hline $\begin{array}{l}\text { 33. Molossidae }+ \\
\text { Vespertilionidae }+ \\
\text { Miniopteridae }\end{array}$ & $\begin{array}{l}\text { Wallia } \\
\text { scalopidens }\end{array}$ & 38.0 & 56.0 & $\begin{array}{l}\text { Eiting and Gunnell (2009); Lim (2009); Emerling } \\
\text { et al. (2015) }\end{array}$ \\
\hline $\begin{array}{l}\text { 34. Molossidae }+ \\
\text { Vespertilionidae }+ \\
\text { Miniopteridae }+ \\
\text { Natalidae }\end{array}$ & $\begin{array}{l}\text { Wallia } \\
\text { scalopidens }\end{array}$ & 38.0 & 56.0 & $\begin{array}{l}\text { Eiting and Gunnell (2009); Lim (2009); Emerling } \\
\text { et al. (2015) }\end{array}$ \\
\hline 35. Yangochiroptera & $\begin{array}{l}\text { Tachypteron } \\
\text { franzeni, } \\
\text { Witwatia sigei, } \\
\text { Dizzya exsultans }\end{array}$ & 47.8 & 61.6 & $\begin{array}{l}\text { Storch et al. (2002); Ravel et al. (2012); Emerling } \\
\text { et al. (2015) }\end{array}$ \\
\hline $\begin{array}{l}\text { 36. Furipteridae }+ \\
\text { Noctilionidae }\end{array}$ & $\begin{array}{l}\text { Noctilio } \\
\text { lacrimaelunaris }\end{array}$ & 5.332 & 33.9 & Cozzuol (2006); Emerling et al. (2015) \\
\hline $\begin{array}{l}\text { 37. Phyllostomidae }+ \\
\text { Mormoopidae }\end{array}$ & $\begin{array}{l}\text { Mormoopid, gen. } \\
\text { et sp. nov. }\end{array}$ & 28.1 & 41.3 & $\begin{array}{l}\text { Morgan and Czaplewski (2003); Gunnell and } \\
\text { Simmons (2005); Czaplewski et al. (2008); } \\
\text { Emerling et al. (2015) }\end{array}$ \\
\hline 38. Erinaceidae & $\begin{array}{l}\text { Neurogymnurus } \\
\text { indricotherii, } \\
\text { Palaeoscaptor } \\
\text { acridens }\end{array}$ & 28.1 & 47.8 & Meredith et al. (2011) \\
\hline $\begin{array}{l}\text { 39. Erinaceidae + } \\
\text { Soricidae }\end{array}$ & Adunator ladae & 61.6 & 83.8 & $\begin{array}{l}\text { Benton et al. (2009, 2015); Meredith et al. (2011); } \\
\text { dos Reis et al. (2012); Emerling et al. (2015) }\end{array}$ \\
\hline 40. Primatomorpha & Purgatorius & 65.2 & 83.8 & $\begin{array}{l}\text { O'Leary et al. (2013); Chester et al. (2015); } \\
\text { Emerling et al. (2015) }\end{array}$ \\
\hline 41. Primates & Numerous & $38.0^{\mathrm{D}}$ & $66.0^{\mathrm{D}}$ & Williams et al. (2010); Benton et al. (2015) \\
\hline
\end{tabular}




\begin{tabular}{|c|c|c|c|c|}
\hline & $\begin{array}{l}\text { eosimiids (e.g., } \\
\text { Eosimias) }\end{array}$ & & & \\
\hline 42. Haplorhini & $\begin{array}{l}\text { Numerous } \\
\text { eosimiids (e.g., } \\
\text { Eosimias, } \\
\text { Phenacopithecus) }\end{array}$ & 38.0 & $59.2^{\mathrm{E}}$ & Williams et al. (2010); Emerling et al. (2015) \\
\hline 43. Strepsirrhini & $\begin{array}{l}\text { Saharagalago } \\
\text { misrensis }\end{array}$ & 38.0 & 56.0 & Seiffert et al. (2003); Emerling et al. (2015) \\
\hline $\begin{array}{l}\text { 44. Galagidae + } \\
\text { Lorisidae }\end{array}$ & $\begin{array}{l}\text { Saharagalago } \\
\text { misrensis }\end{array}$ & 38.0 & 56.0 & Seiffert et al. (2003); Emerling et al. (2015) \\
\hline 45. Lagomorpha & $\begin{array}{l}\text { Tarsals from } \\
\text { Vastan mine }\end{array}$ & $53.7^{\mathrm{F}}$ & 61.6 & $\begin{array}{l}\text { Rose et al. (2008); Emerling et al. (2015); Kapur } \\
\text { and Bajpai (2015); Phillips (2016) }\end{array}$ \\
\hline 46. Rodentia & $\begin{array}{l}\text { Acritoparamys, } \\
\text { Paramys }\end{array}$ & 56.0 & 66.0 & Benton et al. (2015); Emerling et al. (2015) \\
\hline $\begin{array}{l}\text { 47. Sciuromorpha to } \\
\text { Hystricognathi }\end{array}$ & Acritoparamy & 56.0 & 66.0 & $\begin{array}{l}\text { Korth (1994); Anderson (2008); Janis et al. } \\
\text { (2008); Emerling et al. (2015) }\end{array}$ \\
\hline 48. Sciuromorpha & Eogliravus & 47.8 & 61.6 & Meredith et al. (2011); Emerling et al. (2015) \\
\hline $\begin{array}{l}\text { 49. Aplodontidae }+ \\
\text { Sciuridae }\end{array}$ & Spurimus & 45.7 & 59.2 & Flynn and Jacobs (2008a); Meredith et al. (2011) \\
\hline $\begin{array}{l}\text { 50. Diatomyidae }+ \\
\text { Ctenodactylidae }\end{array}$ & Fallomus & 28.3 & 47.8 & $\begin{array}{l}\text { Dawson et al. (2008); Meredith et al. (2011); } \\
\text { Emerling et al. (2015) }\end{array}$ \\
\hline 51. Hystricognathi & $\begin{array}{l}\text { Cachiyacuy } \\
\text { contamanensis }\end{array}$ & 40.94 & 56.0 & $\begin{array}{l}\text { Hartenberger (1998); Antoine et al. (2011); } \\
\text { Emerling et al. (2015); Phillips (2015) }\end{array}$ \\
\hline $\begin{array}{l}\text { 52. Phiomorpha }+ \\
\text { Caviomorpha }\end{array}$ & $\begin{array}{l}\text { Cachiyacuy } \\
\text { contamanensis }\end{array}$ & 40.94 & 56.0 & $\begin{array}{l}\text { Hartenberger (1998); Antoine et al. (2011); } \\
\text { Emerling et al. (2015); Phillips (2015) }\end{array}$ \\
\hline $\begin{array}{l}\text { 53. Caviidae + } \\
\text { Dasyproctidae }\end{array}$ & $\begin{array}{l}\text { Asteromys, } \\
\text { Chubutomys }\end{array}$ & 24.5 & 38.0 & $\begin{array}{l}\text { Vucetich et al. (1999); Campbell and Frailey } \\
\text { (2004); Frailey and Campbell (2004); Emerling et } \\
\text { al. (2015) }\end{array}$ \\
\hline $\begin{array}{l}\text { 54. Chinchillidae }+ \\
\text { Dinomyidae }\end{array}$ & Eoviscaccia & 24.5 & 38.0 & Vucetich et al. (1999); Emerling et al. (2015) \\
\hline
\end{tabular}




\begin{tabular}{|c|c|c|c|c|}
\hline $\begin{array}{l}\text { 55. Chinchillidae }+ \\
\text { Dinomyidae }+ \\
\text { Abrocoma }+ \\
\text { Octodontoidea }\end{array}$ & $\begin{array}{l}\text { Sallamys, } \\
\text { Xylechimys, } \\
\text { Deseadomys }\end{array}$ & 24.5 & 38.0 & $\begin{array}{l}\text { Flynn and Swisher (1995); Flynn and Wyss } \\
\text { (1998); Vucetich et al. (1999); Emerling et al. } \\
\text { (2015) }\end{array}$ \\
\hline 56. Octodontoidea & $\begin{array}{l}\text { Sallamys, } \\
\text { Xylechimys, } \\
\text { Deseadomys }\end{array}$ & 24.5 & 38.0 & $\begin{array}{l}\text { Flynn and Swisher (1995); Flynn and Wyss } \\
\text { (1998); Vucetich et al. (1999); Emerling et al. } \\
\text { (2015) }\end{array}$ \\
\hline $\begin{array}{l}\text { 57. Ctenomyidae }+ \\
\text { Octodontidae }\end{array}$ & $\begin{array}{l}\text { Xenodontomys, } \\
\text { Palaeoctodon, } \\
\text { Chasicomys }\end{array}$ & 9.07 & 33.9 & $\begin{array}{l}\text { Vucetich et al. (1999); Zárate et al. (2007); } \\
\text { Emerling et al. (2015) }\end{array}$ \\
\hline $\begin{array}{l}58 . \\
\text { Anomaluromorpha }^{\mathrm{G}}+ \\
\text { Myomorpha }^{\mathrm{G}}\end{array}$ & Erlianomys & 54.0 & 61.6 & Li and Meng (2010) \\
\hline $\begin{array}{l}\text { 59. Myomorpha } \\
\text { (Muroidea }+ \\
\text { Dipodoidea) }\end{array}$ & Pappocricetodon & 45.0 & 59.2 & Beard et al. (1994); Emerling et al. (2015) \\
\hline $\begin{array}{l}\text { 60. Castorimorpha }+ \\
\text { Anomaluromorpha }+ \\
\text { Myomorpha }\end{array}$ & Erlianomys & 54.0 & 66.0 & Li and Meng (2010); Meredith et al. (2011) \\
\hline 61. Geomyoidea & Proheteromys & 31.4 & 41.3 & $\begin{array}{l}\text { Flynn et al. (2008); Meredith et al. (2011); } \\
\text { Emerling et al. (2015) }\end{array}$ \\
\hline 62. Scandentia & Ptilocercus ${ }^{\mathrm{H}}$ & 34.0 & 66.0 & Emerling et al. (2015); Li and Ni (2016) \\
\hline
\end{tabular}

${ }^{\mathrm{A}}$ Kear and Pledge (2008) recovered Macropodoidea with $100 \%$ bootstrap support, but within this clade there was only $51 \%$ support for an association of the advanced bulungamayine Bulungamaya with Macropodidae. Nevertheless, Bulungamaya is three nodes upwards from the macropodoid node and shares four unambiguous apomorphies with Macropodidae to the exclusion of Potoroidae and more primitive bulungamayines. Kear and Pledge's (2008) recommendation that Potoroidae and Bulungamayinae be treated as incertae sedis within Macropodoidea is concerned with the association of basal bulungamayines (Ngamoroo, Purtia, Wakiewakie) with either potoroids or macropodids + advanced bulungamayines. 
${ }^{\mathrm{B}}$ We used maximum age suggested by Emerling et al. (2015).

${ }^{\mathrm{C}}$ Phillips (2016) suggests that the placement of Tachypteron franzeni is highly speculative, but Storch et al. (2002) reported that the "proportions of the strikingly narrow wing, the outline of the flight membranes and external ear, the morphology of the postcranial skeleton, and the relative cochlea size of T. franzeni and extant Taphozous species are almost identical" and that $T$. franzeni represents the oldest unequivocal record of Emballonuridae."

${ }^{D}$ Benton et al. (2015) suggest a minimum age of 56.0 for crown Primates (Euprimates) based on the inclusion of the late Paleocene Altiatlasius in this clade, but this taxon may be a stem euprimate (Bloch et al., 2007; Williams et al., 2010). Similarly, Benton et al. (2015) suggested a maximum age of 66.0 Ma for Primates based on early Paleocene deposits that have yielded fossils of plesiadapids, paromomyids, and carpolestids, which are reconstructed as being more closely related to crown primates than to Scandentia or Dermoptera.

${ }^{\mathrm{E}}$ The maximum age for Haplorhini allows for the possibility that the late Paleocene Altiatlasius from Morocco is a stem anthropoid (Williams et al. 2010).

${ }^{\mathrm{F}}$ Kapur and Bajpai (2015) provide an updated age for the Vastan tarsals (Rose et al., 2008) that are associated with Leporidae.

GThe minimum for Myomorpha + Anomaluromorpha is established by Erlianomys, which is the oldest stem Myodonta at $~ 54$ Ma (Li and Meng, 2010). The stratigraphic bounding maximum (sensu Meredith et al., 2011) is 61.6 Ma.

${ }^{\mathrm{H}} \mathrm{Li}$ and Ni (2016) described Ptilocercus fossils from the early Oligocene ( 34.0 Ma) of China, which establish a minimum age for crown Scandentia. The putative scandentian Eodendrogale parva is slightly older ( $38.0 \mathrm{Ma})$, but the original fossil specimens are missing (Ni and Qui, 2012) and the published illustrations of Tong (1998) do not provide sufficient evidence for allocating E. parva to Scandentia (Ni and Qui, 2012). We followed Emerling et al. (2015) for the maximum age of 66.0 Ma. 
Table 2. Compendium of zombie lineages implied by Phillips' (2016) preferred timetree ${ }^{\mathrm{A}}$.

\begin{tabular}{|c|c|c|c|c|c|}
\hline Clade & Phillips' Age (Ma) & $\begin{array}{l}\text { Minimum Fossil Age } \\
(\mathrm{Ma})\end{array}$ & Zombie Lineage (Ma) & Oldest Fossil & $\begin{array}{l}\text { References for oldest } \\
\text { fossil/age }\end{array}$ \\
\hline Hyracoidea & 3.12 & 6.08 & 2.96 & Dendrohyrax & $\begin{array}{l}\text { Pickford and Hlusko } \\
\text { (2007); Emerling et } \\
\text { al. (2015) }\end{array}$ \\
\hline Proboscidea & 1.27 & 6.8 & 5.53 & Loxodonta & $\begin{array}{l}\text { Vignaud et al. (2002); } \\
\text { Lebatard et al. (2008); } \\
\text { Emerling et al. (2015) }\end{array}$ \\
\hline $\begin{array}{l}\text { Hyracoidea to } \\
\text { Proboscidea }\end{array}$ & 44.63 & 59.2 & 14.57 & Eritherium & Emerling et al. (2015) \\
\hline Sirenia & 5.74 & 41.3 & 35.56 & Eotheroides & $\begin{array}{l}\text { Vélez-Juarbe and } \\
\text { Domning (2014, } \\
\text { 2015); Springer et al. } \\
\text { (2015) }\end{array}$ \\
\hline Paenungulata & 45.17 & 59.2 & 14.03 & Eritherium & $\begin{array}{l}\text { Gheerbrant (2009); } \\
\text { Kocsis et al. (2014) }\end{array}$ \\
\hline Tardigrada & 13.74 & 15.97 & 2.23 & Imagocnus & MacPhee et al. (2003) \\
\hline Xenarthra & 46.83 & 47.8 & 0.97 & Riostegotherium & $\begin{array}{l}\text { Bergqvist et al. } \\
\text { (2004); Woodburne et } \\
\text { al. (2014) }\end{array}$ \\
\hline Antilocapra to Okapia & 13.17 & 17.8 & 4.63 & Canthumeryx & $\begin{array}{l}\text { Theodor (2004); } \\
\text { Drake et al. (1988); } \\
\text { Emerling et al. (2015) }\end{array}$ \\
\hline Bos to Moschus & 12.06 & 18 & 5.94 & Eotragus & $\begin{array}{l}\text { Solounias et al. } \\
\text { (1995); Emerling et } \\
\text { al. (2015) }\end{array}$ \\
\hline $\begin{array}{l}\text { Bos }+ \text { Moschus to } \\
\text { Cervus }\end{array}$ & 12.94 & 18 & 5.06 & Eotragus & $\begin{array}{l}\text { Solounias et al. } \\
\text { (1995); Emerling et } \\
\text { al. (2015) }\end{array}$ \\
\hline Pecora & 13.49 & 18 & 4.51 & Eotragus & $\begin{array}{l}\text { Solounias et al. } \\
\text { (1995); Emerling et }\end{array}$ \\
\hline
\end{tabular}




\begin{tabular}{|c|c|c|c|c|c|}
\hline & & & & & al. (2015) \\
\hline Ruminantia & 26.11 & 33.9 & 7.79 & Lophiomerycidae & $\begin{array}{l}\text { Janis and Theodor } \\
\text { (2015) }\end{array}$ \\
\hline $\begin{array}{l}\text { Megaptera to } \\
\text { Eschrichtius }\end{array}$ & 2.53 & 7.246 & 4.716 & Plesiobalaenoptera & Bisconti (2010) \\
\hline $\begin{array}{l}\text { Balaenopteroidea to } \\
\text { Neobalaenidae }\end{array}$ & 3.54 & 23.03 & 19.49 & Mauicetus & $\begin{array}{l}\text { Fordyce } 2005 ; \\
\text { Boessenecker and } \\
\text { Fordyce (2015) }\end{array}$ \\
\hline Mysticeti & 3.92 & 23.03 & 19.11 & Mauicetus & $\begin{array}{l}\text { Fordyce } 2005 ; \\
\text { Boessenecker and } \\
\text { Fordyce (2015) }\end{array}$ \\
\hline $\begin{array}{l}\text { Monodontidae to } \\
\text { Phocoenidae }\end{array}$ & 3.6 & 12.1 & 8.5 & Salumiphocoena & $\begin{array}{l}\text { Barnes (1976); Uhen } \\
\text { et al. (2008); } \\
\text { Emerling et al. (2015) }\end{array}$ \\
\hline Delphinoidea & 4.43 & 12.1 & 7.67 & Salumiphocoena & $\begin{array}{l}\text { Barnes (1976); Uhen } \\
\text { et al. (2008) }\end{array}$ \\
\hline Inia to Pontoporia & 5.01 & 6.5 & 1.49 & Iniid humerus & Gutstein et al. (2014) \\
\hline $\begin{array}{l}\text { Delphinoidea to Inia } \\
+ \text { Pontoporia }\end{array}$ & 6.44 & 12.1 & 5.66 & Salumiphocoena & $\begin{array}{l}\text { Barnes (1976); Uhen } \\
\text { et al. (2008) }\end{array}$ \\
\hline $\begin{array}{l}\text { Delphinoidea }+ \\
\text { Inia/Pontoporia to } \\
\text { Ziphiidae }\end{array}$ & 8.24 & 13.2 & 4.96 & Archaeoziphius & $\begin{array}{l}\text { Lambert and Louwye } \\
\text { (2006) }\end{array}$ \\
\hline $\begin{array}{l}\text { Odontoceti minus } \\
\text { Physeteroidea }\end{array}$ & 8.46 & 15.97 & 7.51 & $\begin{array}{l}\text { Prepomatodelphis } \\
\text { korneuburgensis }\end{array}$ & Barnes (2002) \\
\hline Physeteroidea & 6.26 & 13.82 & 7.56 & Idiophyseter & $\begin{array}{l}\text { Bianucci and Landini } \\
\text { (2006); Paleobiology } \\
\text { Database }\end{array}$ \\
\hline Odontoceti & 8.77 & 23.03 & 14.26 & Ferocetotherium & $\begin{array}{l}\text { Lambert et al., 2008; } \\
\text { Gol'din and } \\
\text { Marareskul, } 2013\end{array}$ \\
\hline Cetacea & 9.12 & 34 & 24.88 & Llanocetus & Uhen (2010) \\
\hline Whippomorpha & 33.61 & 52.5 & 18.89 & Himalayacetus & Meredith et al. (2011) \\
\hline Cetruminantia & 36.96 & 52.5 & 15.54 & Himalayacetus & Meredith et al. (2011) \\
\hline
\end{tabular}




\begin{tabular}{|c|c|c|c|c|c|}
\hline $\begin{array}{l}\text { Cetruminantia + } \\
\text { Suina }\end{array}$ & 42.64 & 52.5 & 9.86 & Himalayacetus & Meredith et al. (2011) \\
\hline Cetartiodactyla & 45.4 & 52.5 & 7.1 & Himalayacetus & Meredith et al. (2011) \\
\hline Prionodon to Felis & 17.2 & 28.1 & 10.9 & Proailurus, Stenogale & Emerling et al. (2015) \\
\hline Felidae to Eupleridae & 19.96 & 28.1 & 8.14 & Proailurus, Stenogale & Holliday (2007) \\
\hline Feliformia & 24.11 & 28.1 & 3.99 & Proailurus, Stenogale & Holliday (2007) \\
\hline $\begin{array}{l}\text { Mustelidae to } \\
\text { Procyonidae }\end{array}$ & 17.38 & 24.8 & 7.42 & Promartes & Finarelli (2008) \\
\hline $\begin{array}{l}\text { Mustelidae + } \\
\text { Procyonidae + } \\
\text { Ailuridae }\end{array}$ & 19.03 & 24.8 & 5.77 & Promartes & Finarelli (2008) \\
\hline $\begin{array}{l}\text { Odobenidae to } \\
\text { Otariidae }\end{array}$ & 3.84 & 16.6 & 12.76 & Proneotherium & $\begin{array}{l}\text { Boessenecker and } \\
\text { Churchill (2015) }\end{array}$ \\
\hline Pinnipedea & 7.81 & 20.43 & 12.62 & Desmatophoca & Demere et al. (2003) \\
\hline $\begin{array}{l}\text { Pinnipedea + } \\
\text { Musteloidea }\end{array}$ & 24.08 & 24.8 & 0.72 & Promartes & Finarelli (2008) \\
\hline Arctoidea & 24.35 & 28.1 & 3.75 & Cephalogale & $\begin{array}{l}\text { Banyue and } \\
\text { Zhanxiang (2003); } \\
\text { Wang et al. (2005); } \\
\text { Finarelli (2008); }\end{array}$ \\
\hline Caniformia & 30.53 & 38 & 7.47 & Hesperocyon & $\begin{array}{l}\text { Wang and Tedford } \\
\text { (1996); Spaulding and } \\
\text { Flynn (2009) }\end{array}$ \\
\hline Carnivora & 36.68 & 38 & 1.32 & Hesperocyon & $\begin{array}{l}\text { Wang and Tedford } \\
\text { (1996); Spaulding and } \\
\text { Flynn (2009) }\end{array}$ \\
\hline Ceratomorpha & 25.28 & 53.7 & 28.42 & Cambaylophus & $\begin{array}{l}\text { Kapur and Bajpai } \\
(2015)\end{array}$ \\
\hline Perissodactyla & 27.9 & 55.5 & 27.6 & Hyracotherium & $\begin{array}{l}\text { Woodburne et al. } \\
\text { (2009) }\end{array}$ \\
\hline Ostentoria & 59.35 & 64 & 4.65 & Ravenictis & Fox et al. (2010) \\
\hline Zoomata & 61.22 & 64 & 2.78 & Ravenictis & Fox et al. (2010) \\
\hline Hipposideridae to & 28.5 & 38 & 9.5 & Hipposideros & Gunnell and Simmons \\
\hline
\end{tabular}




\begin{tabular}{|c|c|c|c|c|c|}
\hline Rhinolophidae & & & & & $\begin{array}{l}\text { (2005); Eiting and } \\
\text { Gunnell (2009) }\end{array}$ \\
\hline $\begin{array}{l}\text { Emballonuridae to } \\
\text { Nycteridae }\end{array}$ & 38.95 & 47.6 & 8.65 & Tachypteron & $\begin{array}{l}\text { Storch et al. (2002); } \\
\text { Gunnell and Simmons } \\
\text { (2005); Eiting and } \\
\text { Gunnell (2009) }\end{array}$ \\
\hline $\begin{array}{l}\text { Noctilionoidea to } \\
\text { Emballonuridae + } \\
\text { Nycteridae }\end{array}$ & 42.46 & 47.6 & 5.14 & Tachypteron & $\begin{array}{l}\text { Storch et al. (2002); } \\
\text { Gunnell and Simmons } \\
\text { (2005); Eiting and } \\
\text { Gunnell (2009) }\end{array}$ \\
\hline $\begin{array}{l}\text { Erinaceidae to } \\
\text { Soricidae }\end{array}$ & 55.32 & 61.6 & 6.28 & Adunator & $\begin{array}{l}\text { Benton et al. (2009, } \\
2015)\end{array}$ \\
\hline $\begin{array}{l}\text { Erinaceidae }+ \\
\text { Soricidae to Talpidae }\end{array}$ & 58.46 & 61.6 & 3.14 & Adunator & $\begin{array}{l}\text { Benton et al. (2009, } \\
2015)\end{array}$ \\
\hline Eulipotyphla & 59.12 & 61.6 & 2.48 & Adunator & $\begin{array}{l}\text { Benton et al. (2009, } \\
\text { 2015) }\end{array}$ \\
\hline Fereuungulata & 61.48 & 64 & 2.52 & Ravenictis & Fox et al. (2010) \\
\hline Variamana & 61.6 & 64 & 2.4 & Ravenictis & Fox et al. (2010) \\
\hline Hominoidea & 9.74 & 12.68 & 2.94 & Sivapithecus & $\begin{array}{l}\text { Finarelli and Clyde } \\
\text { (2004) }\end{array}$ \\
\hline Catarrhini & 15.55 & 20.55 & 5 & Afropithecus & $\begin{array}{l}\text { Finarelli and Clyde } \\
\text { (2004); Harrison and } \\
\text { Andrews (2009) }\end{array}$ \\
\hline Callithrix to Cebus & 8.35 & 11.8 & 3.45 & Aotus dindensis & $\begin{array}{l}\text { Setoguchi and } \\
\text { Rosenberger (1987); } \\
\text { Antoine et al. (2007); } \\
\text { Springer et al. (2012) }\end{array}$ \\
\hline $\begin{array}{l}\text { Callithrix }+ \text { Cebus }+ \\
\text { Ateles }\end{array}$ & 9.41 & 11.8 & 2.39 & Aotus dindensis & $\begin{array}{l}\text { Setoguchi and } \\
\text { Rosenberger (1987); } \\
\text { Antoine et al. (2007); } \\
\text { Springer et al. (2012) }\end{array}$ \\
\hline Anthropoidea & 21.7 & 28.1 & 6.4 & Aegyptopithecus & Kay et al. (2008) \\
\hline Lorisiformes & 15.04 & 38 & 22.96 & Saharagalago & Seiffert et al. (2003) \\
\hline
\end{tabular}




\begin{tabular}{|c|c|c|c|c|c|}
\hline Lagomorpha & 41.09 & 53.7 & 12.61 & Vastan tarsals & $\begin{array}{l}\text { Rose et al. (2008); } \\
\text { Kapur and Bajpai } \\
(2015)\end{array}$ \\
\hline Octodontoidea & 23.46 & 24.5 & 1.04 & $\begin{array}{l}\text { Sallamys, Xylechimys, } \\
\text { Deseadomys }\end{array}$ & $\begin{array}{l}\text { Vucetich et al. (1999); } \\
\text { Flynn and Swisher } \\
\text { (1995); Flynn and } \\
\text { Wyss (1998); } \\
\text { Emerling et al. (2015) }\end{array}$ \\
\hline $\begin{array}{l}\text { Aplodontidae + } \\
\text { Sciuridae }\end{array}$ & 40.28 & 45.7 & 5.42 & Spurimus & $\begin{array}{l}\text { Flynn and Jacobs } \\
\text { (2008a) }\end{array}$ \\
\hline Geomyoidea & 27.01 & 31.4 & 4.39 & Proheteromys & Flynn et al. (2008) \\
\hline Castorimorpha & 51.46 & 52.4 & 0.94 & Mattimys & $\begin{array}{l}\text { Flynn and Jacobs } \\
\text { (2008b) }\end{array}$ \\
\hline
\end{tabular}

APhillips' (2016) timetree based on 27 calibrations from dos Reis (2012) with modified maximum constraints for Chiroptera, Primates, and Rodentia. Zombie lineages that exceed 20 million years are highlighted in bold font. 
Table 3. Interordinal divergence times (millions of years) and 95\% credibility intervals within Placentalia based on molecular dating analyses with mcmctree and Meredith et al.'s (2011) nucleotide data set for mammalian taxa after excluding 47 taxa that exceed body size and/or longevity thresholds. Analyses were performed with 62 calibrated nodes (Table 1) and four different combinations of evolutionary rate model (autocorrelated rates [AUTO], independent rates [IR]) and calibration type (hard bounded [HARD], soft bounded [SOFT]).

\begin{tabular}{|c|c|c|c|c|c|c|}
\hline \multirow[t]{2}{*}{ Clade } & \multicolumn{4}{|c|}{ Analysis } & \multirow{2}{*}{$\begin{array}{c}\text { Mean date } \\
\text { from Meredith } \\
\text { et al. }(2011)^{\mathrm{A}}\end{array}$} & \multirow{2}{*}{$\begin{array}{l}\text { Mean date } \\
\text { from dos Reis } \\
\text { et al. }(2012)^{\mathrm{B}}\end{array}$} \\
\hline & AUTO, HARD & IR, HARD & AUTO, SOFT & IR, SOFT & & \\
\hline Placentalia & $90.3(88.2,92.6)$ & $92.8(90.0,95.9)$ & $93.5(91.1,96.0)$ & $91.3(88.4,94.6)$ & 101.35 & 90.9 \\
\hline Afrotheria & $75.2(73.2,77.8)$ & $76.7(73.8,80.6)$ & $77.4(74.9,80.3)$ & $75.8(71.7,79.6)$ & 80.89 & 71.3 \\
\hline Afroinsectivora & $72.3(70.2,74.9)$ & $73.5(70.5,77.4)$ & $74.3(71.9,77.2)$ & $72.7(68.5,76.4)$ & 77.33 & NA \\
\hline Exafroplacentalia & $87.5(85.8,89.5)$ & $89.4(86.9,92.2)$ & $90.7(88.7,92.8)$ & $88.1(85.5,90.9)$ & 99.38 & 90.2 \\
\hline Boreoeutheria & $81.2(79.9,82.5)$ & $82.6(80.7,84.7)$ & $83.9(82.4,85.6)$ & $81.5(79.6,83.8)$ & 92.0 & 82.8 \\
\hline Laurasiatheria & $75.0(73.9,76.1)$ & $75.9(74.0,78.1)$ & $77.1(75.6,78.70$ & $74.4(72.2,77.2)$ & 84.56 & 75.3 \\
\hline Variamana & $73.4(72.3,74.6)$ & $74.0(72.1,76.2)$ & $75.4(73.8,76.9)$ & $72.5(70.2,75.4)$ & 82.02 & 72.9 \\
\hline Fereuungulata & $72.8(71.6,74.1)$ & $73.4(71.4,75.7)$ & $74.8(73.2,76.3)$ & $72.0(69.5,74.9)$ & 81.98 & NA \\
\hline Ostentoria & $70.4(69.0,71.8)$ & $70.3(68.0,72.7)$ & $72.4(70.6,74.0)$ & $68.9(66.2,71.9)$ & 79.62 & NA \\
\hline Euarchontoglires & $75.1(74.3,76.1)$ & $76.1(74.6,77.7)$ & $77.6(76.3,78.8)$ & $75.8(74.4,77.6)$ & 83.33 & 75.6 \\
\hline Primatomorpha & $73.3(72.3,74.4)$ & $74.4(72.6,76.3)$ & $76.3(74.9,77.6)$ & $74.2(72.3,76.1)$ & 82.04 & NA \\
\hline $\begin{array}{l}\text { Glires + } \\
\text { Scandentia }\end{array}$ & $74.7(73.8,75.6)$ & $75.6(74.1,77.2)$ & $77.0(75.8,78.3)$ & $75.4(73.9,77.1)$ & 82.78 & NA \\
\hline Glires & $72.3(71.5,73.1)$ & $73.1(71.8,74.6)$ & $74.2(73.0,75.4)$ & $73.1(71.8,74.7)$ & 79.5 & 70.7 \\
\hline
\end{tabular}

Abbreviations: NA, not reported or clade not applicable on dos Reis et al.'s (2012) tree.

${ }^{A}$ Mean dates based on table S6 of Meredith et al. (2011).

${ }^{\mathrm{B}}$ Mean dates based on four analyses reported in table 1 of dos Reis et al. (2012). 
Table 4. Results of Templeton and winning-sites tests.

\begin{tabular}{|l|l|l|l|}
\hline Trees & Length & Templeton p value & $\begin{array}{l}\text { Winning-sites } \mathrm{p} \\
\text { value }\end{array}$ \\
\hline $\begin{array}{l}\text { Cretaceous taxa on } \\
\text { placental stem (3 } \\
\text { trees) }\end{array}$ & 2293 & 1.00 & 1.00 \\
\hline Molecular scaffold & 2319 & & \\
(6 trees) & & $0.0073^{*}$ & $0.0099^{*}$ \\
& & $0.0086^{*}$ & $0.0116^{*}$ \\
& $0.0108^{*}$ & $0.0138^{*}$ \\
& & $00108^{*}$ & $0.0138^{*}$ \\
& & $0.0124^{*}$ & $0.0159^{*}$ \\
Zalambdalestidae + & 2318 & $0.0124^{*}$ & $0.0159^{*}$ \\
\hline Glires (6 trees) & & $0.0461^{*}$ & $0.0171^{*}$ \\
& & $0.0473^{*}$ & $0.0215^{*}$ \\
& & $0.0499^{*}$ & $0.0240^{*}$ \\
& & 0.0509 & $0.0298^{*}$ \\
& & 0.0588 & 0.0622 \\
\end{tabular}

Templeton and winning-sites test were performed to determine if there are statistically significant differences between different trees. Tests were performed with PAUP*. Trees with minimum branch lengths of zero were collapsed. 


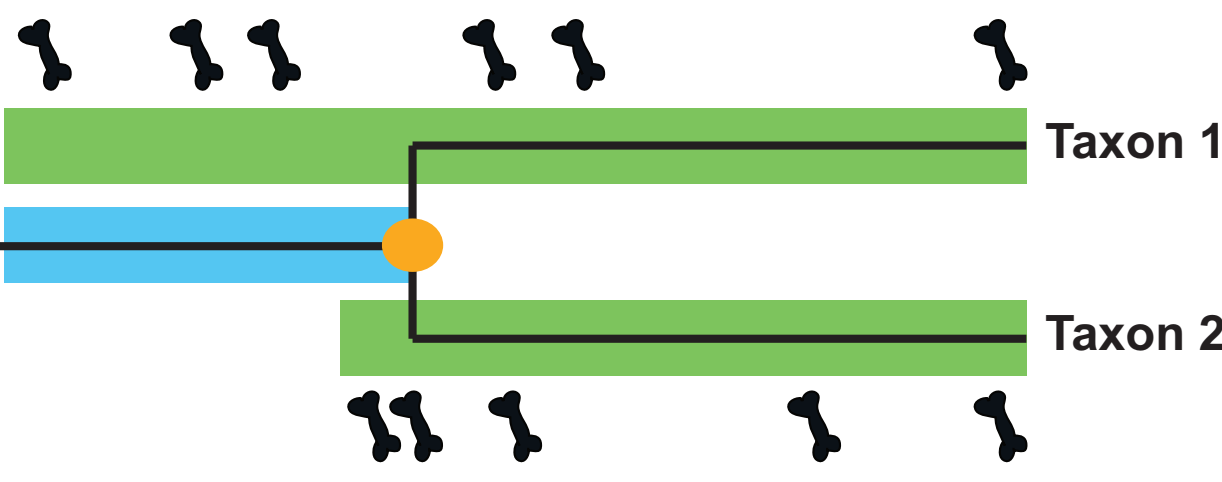

Time

= estimated divergence time between taxon 1 and taxon 2

$=$ fossil occurrence

= observed taxon range

$=$ zombie lineage resulting from crown fossil(s) that are older than timetree estimate 